\title{
The Ins and Outs of Poverty in Advanced Economies: Poverty Dynamics in Canada, Germany, Great Britain, and the United States
}

\author{
Robert G. Valletta \\ Federal Reserve Bank of San Francisco
}

Working Paper 2004-18

http://www.frbsf.org/publications/economics/papers/2004/wp04-18bk.pdf

The views in this paper are solely the responsibility of the authors and should not be interpreted as reflecting the views of the Federal Reserve Bank of San Francisco or the Board of Governors of the Federal Reserve System. 


\title{
"The Ins and Outs of Poverty in Advanced Economies: Poverty Dynamics in Canada, Germany, Great Britain, and the United States."
}

\author{
Rob Valletta* \\ Economic Research Department \\ Federal Reserve Bank of San Francisco \\ 101 Market Street \\ San Francisco, CA 94105 USA \\ (415) 974-3345 \\ fax: (415) 977-4084 \\ rob.valletta@sf.frb.org
}

November 8, 2004

\begin{abstract}
$\underline{\text { Abstract }}$
Comparative analysis of poverty dynamics-incidence, transitions, and persistence - can yield important insights about the nature of poverty and the effectiveness of alternative policy responses. This manuscript compares poverty dynamics in four advanced industrial countries (Canada, unified Germany, Great Britain, and the United States) for overlapping six-year periods in the 1990s. The data indicate that poverty persistence is higher in North America than in Europe; for example, despite high incidence, poverty in Great Britain is relatively transitory. Most poverty transitions, and the prevalence of chronic poverty, are associated with employment instability and family dissolution in all four countries. The results also suggest that differences in social policy are crucial for the observed differences in poverty incidence and persistence between Europe and North America.
\end{abstract}

* For their comments, the author thanks Mary Daly and seminar participants at the June 2002 Federal Reserve System Applied Microeconomics meeting and the May 2003 meeting of Bay Area Labor Economists (especially Peggy O'Brien-Strain). This work is based in part on the author's contribution to Chapter 2 of the OECD Employment Outlook June 2001 (in conjunction with Paul Swaim and Agnés Puymoyen). Howard Lin and especially Geoff MacDonald provided invaluable research support. Special thanks go to Dean Lillard of Cornell University for his help with the CNEF files, various staff at Statistics Canada for their help with the Canadian SLID portion of the CNEF, and Stephen Jenkins for advice on use of the BHPS portion of the CNEF. None of these individuals are responsible for any errors. The views expressed in this paper are those of the author and should not be attributed to the Federal Reserve Bank of San Francisco or the Federal Reserve System. 


\section{"The Ins and Outs of Poverty in Advanced Economies: Poverty Dynamics in Canada, Germany, Great Britain, and the United States."}

\section{Introduction}

Inequality in market income increased in many industrialized countries in the 1980s and 1990s (Förster 2000, Gottschalk and Smeeding 2000, Smeeding 2000). Much of the growing interest in cross-country comparisons of income inequality has centered on families at the bottom end of the income distribution-those in poverty-because they face the greatest challenges for maintaining a socially acceptable living standard and they account for a substantial share of government program costs.

Cross-country poverty comparisons mostly have focused on poverty rates at a point in time or trends over time (e.g. Biewen and Jenkins 2002, Blackburn 1998, Jäntti and Danziger 2000, Smeeding et al. 2000). Often an additional focus is on the impact of government social-welfare policies on poverty, with the intent being to aid the development of effective anti-poverty strategies. To fully understand poverty from a socio-economic and policy perspective, however, it is important to move beyond static comparisons of cross-section poverty by analyzing the dynamics of poverty. "Poverty dynamics" refers to the poverty flow patterns — transitions and persistence — that underlie the observed poverty rate at a point in time.

This manuscript updates and extends existing comparative work on poverty dynamics in advanced economies, focusing on Canada, Germany, Great Britain, and the United States. The data are from the Cross National Equivalent Files, which provide nationally representative panels that have been extensively analyzed and processed to 
enhance the comparability of variable definitions and content (Burkhauser et al. 2001). From these data, overlapping 6-year panels from the 1990s are formed for each country and are used to analyze poverty dynamics and the role of related characteristics such as family structure and work status, for individuals in households with working-age heads. Poverty is measured in relative terms using income both before and after the impact of government tax and transfer policies. In addition, standard headcounts of individuals whose annual equivalent household income falls below the poverty threshold are supplemented by a measure of chronic poverty, which relies on longer-term income flows (Rodgers and Rodgers 1993). Relative to existing research, the primary contributions of this analysis are the use of harmonized data for four advanced industrial economies in North America and Europe, direct examination of the impact of government tax and transfer policies, and the use of regression analyses as well as descriptive analyses of the impact of family structure and employment status on poverty transitions and persistence.

Section 2 provides a brief review of existing comparative analyses of poverty incidence and dynamics, followed by a description of the data and key definitions in Section 3. Section 4 presents descriptive results for poverty transitions and duration, while Section 5 introduces and discusses results from corresponding logit regression analyses. Section 6 summarizes the results and briefly discusses their policy implications. The results reveal widespread similarities in the pattern and causes of poverty transitions and persistence across countries, although the picture that emerges suggests longer and more concentrated poverty in North America than in Europe. Compared with other countries in the sample, in the United States the burden of poverty 
falls heavily on a few high risk groups and is relatively unaffected by government tax and transfer policies.

\section{Cross-Country Poverty Comparisons}

Rising income inequality in advanced economies over the past few decades, and its implications for poverty, have been the subject of a large and growing body of research. Although this research typically focuses on the experiences of individual countries, comparative analyses are likely to be especially useful for policy design. Many advanced industrial countries have experienced similar trends in regard to key poverty determinants, such as earnings inequality and family structure, but not in regard to the extent and patterns of poverty. As such, cross-country poverty comparisons can provide unique insights into the role of economic and institutional influences on poverty outcomes.

Until the late 1980s, the lack of harmonized cross-country data sources largely precluded comparative studies of income inequality and poverty. Since then, several data sources have been developed that provide relatively consistent measurement of income and other variables across countries. The largest of these is the Luxembourg Income Study (LIS), which has provided harmonized data for a growing number of countries (now 25) since about the mid-1980s. The LIS has been used extensively to assess comparative developments in income inequality, poverty, and living standards (for example, Blackburn 1998, Osberg 2000, Smeeding 2000).

The LIS data are based on static cross-sections, but the analysis of poverty dynamics requires panel data that follows individuals and families over time. The U.S. 
Panel Study of Income Dynamics (PSID) has been available for this purpose since the early 1980s; subsequently, similar data sets have been developed for other countries. Reliable comparisons across countries, however, require that key variables be based on harmonized definitions and measurement. One approach to doing so is to design a multicountry household panel survey. A recent example is the European Community Household Panel (ECHP), administered in 15 European countries during the years 19942001. ECHP data for the years 1994-1996 were used in a recent comparative study of poverty dynamics (OECD 2001), but these data are costly to analyze and do not extend to North America. An alternative approach is to take existing household panel surveys and form comparable income and related variables. This is the approach taken in the CrossNational Equivalent Files (CNEF).

The CNEF provides multi-year household panel data from the 1980s and 1990s for four advanced industrial countries: Canada, Germany, Great Britain, and the United States. These four countries provide a useful set of comparisons in regard to poverty. ${ }^{1}$ They are at similar levels of economic development and in general have faced a similar set of socio-economic factors—such as rising returns to skill and changes in family structure- that contributed to rising inequality in earnings and family income (for example, see the various contributions in McFate, Lawson, and Wilson 1995 regarding changes during the 1980s). However, these four countries have faced a different and changing set of institutional influences in the 1980s and 1990s, which had different impacts on income inequality and poverty in each. These institutional changes include

\footnotetext{
${ }^{1}$ The underlying national panels have been used for studies of poverty dynamics in these countries separately, and for limited cross-country comparisons; for example, see Jenkins and Rigg (2001) for Great Britain, Stevens (1999) for the United States, and Jenkins and Schluter (2003) for a comparison of child poverty in Britain and Germany.
} 
reduced reliance on the welfare state in Great Britain and the United States, more precise targeting of income transfers in Canada, and the merger between the former East and West Germany in 1989.

The combination of shared economic determinants but differing political and institutional factors provides a rich environment for comparing trends in inequality and poverty. Most comparative studies of income inequality and poverty have found that the United States and Great Britain saw the largest increases in poverty and inequality during the 1980 s, and that the relatively weak social safety net in the United States is a key reason for higher poverty rates in the United States than in other countries. Such findings are based largely on comparison of poverty rates at a point in time. However, the contribution of underlying determinants of cross-section poverty rates to poverty incidence and persistence is not well understood, suggesting the need for comparative studies of poverty dynamics.

The analysis of poverty dynamics relates conceptually and methodologically to the analysis of unemployment durations (Clark and Summers 1979, Akerlof and Main 1981). To better distinguish between short-term and long-term unemployment, this literature relied on duration-weighted measures of unemployment experience and identified "spurious" unemployment transitions that do not necessarily represent a true change in unemployment status (e.g., movements from unemployed to out-of-labor-force status due to discouragement).

Bane and Ellwood (1986) and Stevens (1999) implemented similar concepts in regard to poverty duration, by examining duration-weighted measures of poverty experience and the incidence of multiple poverty spells. The extent to which the poverty 
population consists of a large number of individuals who experience limited time in poverty, or a small number who face prolonged periods of low income, has important implications for the burden of poverty and the targeting and financing of transfer programs. Similarly, an understanding of the factors that determine poverty transitions is likely to enhance the impact and cost-effectiveness of anti-poverty programs. For example, the contribution of adverse events such as job loss and family dissolution to poverty transitions determines the relative weight that should be placed on economic and social policies to reduce the incidence of these events, as opposed to policies aimed at income maintenance for the poverty population.

Despite the potential importance of poverty dynamics for policy formulation (Burkhauser 2001, Burkhauser and Smeeding 2000), it has been the focus of only limited research in a comparative setting, probably due to data constraints. The comparative poverty chapter from the recent Handbook of Income Distribution Vol. 1 (Jäntti and Danziger 2000) lists only 3 or 4 separate studies of poverty dynamics, the most ambitious of which were written by a lengthy list of scholars from the countries analyzed (Duncan et al. 1993, 1995). Subsequent studies include work done at the OECD (Oxley et al. 2000, OECD 2001) and several studies of the dynamics of child poverty (notably Bradbury, Jenkins, and Micklewright 2001, Jenkins and Schluter 2003). Relative to existing work, the primary contributions of the current paper include: (1) reliance on harmonized data for a set of countries that are reasonably comparable in regard to economic size and status but represent interesting comparisons along geographic and political economy lines; (2) examination of the entire population of individuals in households with working-age heads; (3) direct assessment of the impact of government 
tax and transfer policies; and (4) analysis of the impact of family characteristics and employment status on poverty transitions and persistence in a conditional (regressionbased) framework as well as the unconditional framework used in most past research.

\section{Data and Definitions}

The data used in this study are from the Cross-National Equivalent Files (CNEF), prepared at Cornell University (Burkhauser et al. 2001). These files include data from nationally representative household panels for four countries: the Canadian Survey of Labor and Income Dynamics (SLID), the German Socio-Economic Panel (GSOEP), the British Household Panel Survey (BHPS), and the United States Panel Study of Income Dynamics (PSID). The German sample includes observations from the former East Germany and an oversample of foreign-born guest workers (and their families). ${ }^{2}$ The United States sample includes an oversample of low-income households. Appropriate cross-section and longitudinal weights are employed to ensure that the analysis samples are representative of the population. For maximum comparability across sample definition and years, 6-year panels were constructed for each country: income years 1993-1998 for Canada and income years 1991-1996 for Germany, Great Britain, and the United States. ${ }^{3}$ For each country, the sample was restricted to individuals from

\footnotetext{
${ }^{2}$ Households from the former East Germany were included in the GSOEP as of the 1990 survey (1989 income year), although income data for these households were not recorded until the 1992 survey.

${ }^{3}$ Data are from the February 2004 CNEF release. At this time, the complete CNEF panels include income years 1983-2001 for Germany, 1990-2000 for Great Britain, and 1979-1996, 1998, and 2000 for the United States (after income year 1996, the PSID adopted a biennial sampling scheme). Longitudinal analyses with the Canadian SLID are limited to 6 years, which is the maximum number of years that individuals remain in the panel; these data are only available beginning in income year 1993. These data constraints, and a desire for comparable panels, dictated the selection of overlapping 6-year panels for the 1990s. Compared with the
} 
households with a working-age head (age 64 and under), due to the sharp differences in income dynamics and the structure of government transfers for the elderly versus the rest of the population in most countries. ${ }^{4}$ In addition, child poverty dynamics was not examined separately, although children are included in the samples of individuals used to analyze overall trends in poverty dynamics. ${ }^{5}$

The CNEF files provide data on total household income. One advantage of the CNEF data is the provision of harmonized measures of household income before and after the impact of the complete government tax-and-transfer system in each country. In the analyses below, these two income measures are referred to as "market income" and "disposable income."

Although the household is the unit of measurement for income, we examine poverty dynamics for individuals. This requires the translation of household income to an individual measure, or "equivalent income." To account for economies of scale in intra-household consumption, this is defined as total household income divided by the square root of household size. ${ }^{7}$ The poverty threshold is set at the level of equivalent

alternative Canadian panel (the Longitudinal Administrative Database, or LAD) used by Finnie and Sweetman (2002), the SLID panel is smaller and covers a shorter period, but it provides information on key job characteristics used below for the analysis of poverty transitions.

${ }^{4}$ For example, Germany relies heavily on public pensions for support of senior citizens, which greatly affects analysis of the impact of government transfers on income poverty.

${ }^{5}$ The examination of child poverty can be especially informative in regard to the effects of government programs on poverty, as many programs target low-income families with children. A separate analysis of child poverty dynamics is beyond the scope of this study, although the regression results reported in Section 5 are relevant. See also OECD (2001) for some findings on child poverty dynamics and Bradbury, Jenkins, and Micklewright (2001) for more extensive analyses.

${ }^{6}$ Market income is the sum of total family income from labor earnings, asset flows, private transfers, and private pensions. Disposable income adds public transfers and pensions to market income and subtracts estimated tax payments. See Lillard (2004) for additional details.

${ }^{7}$ The square-root transformation is most commonly used; for equivalence scales that treat adults and children identically, it lies at the midpoint of the range of assumptions regarding economies of scale in consumption. Past cross-country poverty studies have found that the comparative 
disposable household income equal to 50 percent of the median value for each country in each year, and individuals are counted as being in poverty if their equivalent income (market or disposable) falls below that level. The resulting poverty measure is relative rather than absolute-i.e., it does not correspond to an economically meaningful definition of subsistence or impoverishment that is shared across the countries in our sample. Instead, poverty status is measured by relative deprivation within countries. Given the potentially adverse social consequences of relative deprivation, and the difficulties inherent in defining and measuring a common consumption-based income threshold across countries, the relative poverty approach is commonly used in crosscountry poverty comparisons. ${ }^{8}$

The use of a relative threshold leads to higher relative poverty rates in highincome countries than would an absolute threshold. However, analyses using absolute poverty scales adjusted for purchasing power parity suggest that although the British poverty rate rises to a level above that in the United States when an absolute poverty threshold is used, the relative poverty positions of the four countries in our sample otherwise are unchanged (Smeeding et al. 2000). On the other hand, in the United States tax and transfer payments are more closely tied to the official government poverty threshold than to the relative threshold used here. This may bias the assessment of the

results are relatively insensitive to the exact equivalence scale chosen (see e.g. OECD 2001, Annex 2.B).

${ }^{8}$ Although the 50 percent cutoff is commonly employed, other studies and some government agencies have used poverty lines set at 40 percent or 60 percent of median income (for example, the European statistical agency Eurostat uses the latter). In general, the results of comparative studies are not sensitive to these threshold differences (e.g. OECD 2001). However, additional tabulations using the CNEF data (not reported) and results in Smeeding et al.(2000) indicate that the British income distribution is unusually dense between 40 and 50 percent of the median, which implies that the relative British poverty rate falls when the threshold is set at 40 percent rather than 50 percent. 
impact of tax and transfer policies on poverty by systematically understating their impact in the United States. To account for this potential bias, results based on the official U.S. poverty threshold also are presented.

An additional measurement issue relates to the period used to define poverty-level income. A yearly accounting period may be too short to identify the true degree of poverty persistence. In particular, as is common with threshold concepts, some movements above and below the threshold represent changes in income and living standards that are too small to be economically meaningful. ${ }^{9}$ Duncan et al. (1995) and others have handled this problem by restricting poverty transitions to those that involve an income change of at least 20 percent.

A more formal approach was suggested by Rodgers and Rodgers (1993). They noted that by ignoring the degree to which income lies above or below the poverty threshold, studies that analyze the duration of poverty are likely to underestimate the permanence of low living standards. Assuming that borrowing and saving can occur at a prevailing discount rate, they proposed a measure of poverty status that relies on permanent income, or maximum sustainable consumption, relative to permanent needs over multi-year periods. They found that their method increased the measured severity of chronic poverty and revealed an increase in the share of chronic versus transitory poverty in the United States between the late 1970s and early 1980s.

A simplified variant of Rodgers and Rodgers' measure, referred to as "averageincome poverty," is used below. This variable takes the value 1 if average yearly

\footnotetext{
${ }^{9}$ Conversely, because social assistance is tied to income flows over periods shorter than a month in some countries (for example, Great Britain), a yearly measurement period may be too long to capture some short-term movements in income and poverty status that are relevant to social
} 
equivalent income over the six-year sample frame falls below the average poverty

threshold for the same period, and the value 0 otherwise. Duncan and Rodgers (1991), Hill and Jenkins (2001), and the OECD (2001) also used this measure; it corresponds to the special case of Rodgers and Rodgers' measure with the discount rate set to zero. ${ }^{10}$ This measure accounts for long-term income profiles as well as the severity of poverty in a given year (the numerical shortfall of income relative to poverty line), and it eliminates the influence of poverty transitions that reflect small income changes that are unaccompanied by a meaningful change in economic status.

Before turning to the detailed results regarding poverty dynamics, Table 1 provides yearly descriptive statistics for the 6-year panels. For each country and year, the table lists the poverty rates based on market and disposable income, along with the median and standard deviation for the distribution of disposable income (household total, in nominal domestic currency). In this and all tables below, the poverty threshold for market income and disposable income are both set at 50 percent of the median value of equivalent disposable income. Thus, the comparison of market and disposable poverty provides some indication of the impact of government taxes and transfers on the money income of households around a fixed point in the income distribution. These four countries in general saw relatively constant poverty rates in the 1990s, with the primary

policy. Household panel data sets such as those used here typically provide data on yearly income only, thereby precluding analysis of shorter-term poverty dynamics.

${ }^{10}$ The assumption of a zero interest rate has little impact on the specific results obtained in the present setting, and in any case the proper discount rate is unclear. For example, the discount rate perhaps should not be applied symmetrically to a shortfall or excess of income relative to the poverty line, since poor families often are liquidity constrained or may have preferences over the timing of income receipt (Jäntti and Danzier 2000, p. 323). Moreover, some events may preclude inter-year income transfers within households. These considerations suggest that Rodgers and Rodgers' (1993) measure, and the simplified variant used here, may understate the true burden of 
exceptions of rising market income poverty in Germany and a sharp increase in both

poverty rates in the United States between 1995 and $1996 .^{11}$

\section{Descriptive Analyses}

\subsection{Poverty Rates}

To provide a basic sense of how poverty incidence and persistence vary across countries, Table 2 lists average annual poverty rates, the percentage of individuals ever poor, and the prevalence of continuous and chronic poverty (the percentage who are always poor or average-income poor). In terms of disposable (post tax and transfer) income and the relative poverty threshold, Germany has the lowest annual poverty rate and the United States the highest, with Canada and Great Britain in the middle; the spread is wide, with a rate in the United States nearly twice that in Germany. The spread in annual poverty rates is much narrower for market income than disposable income. The wider gap across countries for disposable income poverty than market income poverty reflects substantial variation in the impact of the tax and transfer system across these countries, with an especially small impact in the United States: taxes and transfers reduce the annual poverty rate by just over one percentage point there, compared with six to eight percentage points in the other countries.

The cross-country rankings and spread between the highest and lowest poverty rates is similar for the other measures of poverty in the table as well. Poverty incidence

chronic poverty. Nevertheless, it will do a better job of measuring chronic poverty than spell data, which entirely ignores the shortfall or excess of income relative to the poverty line.

${ }^{11}$ This abrupt measured increase in the U.S. poverty rate based on PSID data conflicts with an official U.S. poverty rate that was relatively flat between 1995 and 1996 (based on yearly income 
and the prevalence of continuous and chronic poverty generally are highest in the United States and lowest in Germany, with Canada and Great Britain generally in between.

There are notable exceptions, however, suggesting that annual poverty rates alone are not adequate indicators for comparing poverty experiences across countries. Compared with its annual poverty rate, Great Britain has a low incidence of individuals always poor or chronically poor, suggesting relative low poverty persistence in Great Britain. Conversely, relative to the percentage of individuals ever poor (poverty incidence), Canada has a high share of individuals always poor or chronically poor, to an extent that is close to that in the United States. In the United States, the comparison of market income poverty and disposable income poverty reveals that the tax and transfer system had little impact on poverty incidence or the prevalence of continuous and chronic poverty.

As noted earlier, however, reliance on a relative poverty threshold may lead to an understatement of the impact of the United States tax and transfer system on poverty, due to the policy focus on the official national poverty threshold rather than the relative poverty threshold used here. To investigate this possibility, Table 2 and selected subsequent tables list poverty tabulations based on the official poverty threshold for the United States. $^{12}$ The U.S. tax and transfer system has a larger impact on poverty based on the official threshold than on the relative threshold; using the official threshold,

data from the Current Population Survey). As has been evident for anomalies in past releases of PSID data, this divergence may be eliminated after further data cleaning in future releases.

${ }^{12}$ Using the official threshold, individuals are identified as being in poverty if their equivalent household income (market or disposable) lies below the poverty threshold for a single-person family. This represents an approximation, as the official U.S. poverty thresholds differ according to family size and composition. However, the approximation is minor, as the implied equivalence scale for the official U.S. poverty threshold is very close to the square root scale used here (Ruggles 1990). 
poverty rates based on the disposable income measure are all noticeably lower those based on the market income measure. Nevertheless, the poverty-reducing impact of taxes and transfers remains smaller in the United States than in the other three countries.

Table 3 sheds additional light on poverty dynamics by listing poverty entry and exit rates and mean duration of poverty spells (completed or incomplete). The lower poverty rates in Germany than elsewhere, identified in Table 2, are largely due to lower poverty entry rates there, although the exit rate based on disposable income is higher in Germany than in Canada or the United States. The relatively transitory nature of British poverty and relatively persistent nature of Canadian poverty identified in Table 2 also can be seen in Table 3. In particular, Great Britain has relatively high entry and exit rates to and from poverty and a relatively low average duration of poverty, while Canada has relatively low exit rates and high mean duration. Use of the official U.S. poverty thresholds reduces the rate of measured poverty entries, with only a small impact on poverty exits.

The relatively low poverty persistence in Germany and Great Britain, and relatively high persistence in Canada in the United States, can be seen in Table 4 as well. The left panel lists the share of total poverty spells that fall into the three duration categories shown. Focusing on poverty durations based on the disposable income measure, in each country about 75 to 80 percent of all spells last 1-2 years. To get a better sense of how widely the burden of poverty is born, however, one should examine the share of total years in poverty attributable to spells of varying durations, as displayed in the right panel of Table $4 .{ }^{13}$ In Canada and the United States, based on the disposable

\footnotetext{
${ }^{13}$ This concept was introduced by Bane and Ellwood (1986) and is closely related to Akerlof and Main's (1981) experience-weighted measure of unemployment duration.
} 
income measure over 35 percent of all time spent in poverty was spent in spells of 5-6 years. The corresponding shares in Germany and Great Britain are about 10-20 percentage points lower, suggesting that poverty durations in general are shorter in those countries.

It is perhaps somewhat surprising to discover that Canada exhibits poverty persistence similar to that in the United States (Tables 2-4). This finding conflicts to some degree with Blank and Hanratty's (1993) findings regarding large poverty-reducing impacts of Canadian social policy, but it is consistent with Duncan et al's (1995) findings regarding high poverty rates and lengthy poverty durations in the United States and Canada compared with European countries. ${ }^{14}$

\subsection{Explanatory Factors}

An assessment of factors associated with poverty transitions and persistence is critical for understanding the broad economic and policy implications of the basic patterns identified in the preceding section. In the remainder of the paper, the focus is on disposable income poverty, to keep the analysis manageable and to direct attention to the income and spending patterns actually experienced by the population in each country (the impact of government taxes and transfers is examined directly in some of the analyses below). The key explanatory factors examined are family relationships within the household and employment status, which have been the focus of past work, along with selected related factors such as the household head's educational attainment.

\footnotetext{
${ }^{14}$ Dinardo and Lemieux (1997) found that despite a smaller increase in earnings inequality in Canada than in the U.S. during the 1980s, earnings gaps in the bottom half of the distribution (e.g., the 10-50 percentile difference) increased by a similar amount in the two countries.
} 
Figures 1-3 display the impact of selected household characteristics on the probabilities of poverty incidence and long-term poverty. Using household characteristics measured in the first year of the panel, each bar represents the ratio of the group share of the poverty population relative to their share of the total population; a value above 1 in each case indicates that the group faces an above-average risk of poverty. The exact tabulations underlying Figures 1-3, along with additional detail, are listed in Appendix Table A.

The figures show that the profile of households facing high poverty risks is similar in the four countries, with some exceptions. In Figure 1, households comprised of a single adult with children face high probabilities of experiencing poverty at least once during the six-year sample frame, especially in Canada and Germany (left panel). Single parents and their children also face by far the greatest risk of average-income poverty (right panel) of the four family types listed; in Great Britain and the United States, this is the only family type whose share of the poverty population is greater than their overall population share. Figure 2 shows that although households headed by an individual with low education face elevated poverty risks in Canada, Germany, and the United States, their risk of average-income poverty is especially high in the United States. ${ }^{15}$ By contrast, in Canada such households face only slighter higher poverty risks than households whose head has at least a high-school education. Finally, Figure 3 shows that households with no workers in the panel base year face very high poverty risks, especially for average-income poverty. Indeed, in all four countries, households with one

\footnotetext{
${ }^{15}$ Data on educational attainment are not available in the BHPS-CNEF panel. The three educational categories used represent educational attainment greater than, equal to, or less than high school (see Lillard 2004 for additional details regarding the German education variables).
} 
or more workers constitute a smaller share of the poverty population than the total population.

Despite the high poverty risks for population sub-groups such as those identified above, these groups can nonetheless constitute a small share of the population of concern for anti-poverty programs. For example, persons living in female-headed and singleparent households are everywhere a minority of the poverty population, despite facing elevated risks (see Appendix Table A for the complete set of tabulations). Consequently, in targeting anti-poverty measures it is important not to focus exclusively on "high-risk" populations. Households with a male head and those with one or more workers do not show up among the high-risk groups, yet they account for the majority of the averageincome poor population in each of these countries.

On the other hand, members of low -risk groups may enter poverty by acquiring a characteristic associated with high-risk groups. This suggests the importance of examining events associated with poverty transitions, which has been the focus of previous studies as well. These results are contained in Tables 5-7. Table 5 focuses first on events related to family relationships or structure within the household. These are important in each country, being associated with about 40 percent or more of all poverty entries and about 25 percent to nearly 40 percent of exits. Despite oft-cited concerns about the correspondence between unstable families and poverty in the United States, changes in family structure generally are related to fewer transitions there than in the other countries examined (except for poverty exits in Germany). Among the reasons for changing family structure, changes in marital status are most frequently associated with 
poverty transitions. In addition, poverty entries often are associated with the establishment of a new household by an individual other than a former head or spouse.

Table 6 displays the relationship between poverty transitions and changes in job status and earnings. Of total poverty entries and exits, about 20 to 30 percent are associated with changes in full-time work status of the household head or spouse, most frequently for the head. The table also indicates the role of more general employment and earnings instability (changes in months at work by the head and spouse, and changes of at least 10 percent in family labor earnings). ${ }^{16}$ Compared with Germany and Great Britain, poverty entries in Canada and the United States are less frequently associated with the loss of a full-time job and poverty exits are more frequently associated with an increase in months worked.

Because household job loss can be due to family events such as divorce, Table 7 provides more insight on the respective roles of family and employment events by combining the separate analyses from Tables 5 and 6 . After first accounting for poverty transitions associated with any change in family structure, the table then lists sequentially the share of transitions associated with changes in the number of workers and changes in primary sources of income (based on a mutually exclusive hierarchical ordering). Among the four countries, changes in family structure are most commonly associated with poverty transitions in Canada. In the United States, an especially large share of poverty transitions are associated with changes in earnings (conditional on the number of

\footnotetext{
${ }^{16}$ In the PSID data for the United States, data on hours worked are not available for individuals other than the head and spouse after income year 1992. This necessitated the restriction of the full-time work and months worked variables to the head and spouse for all countries, for appropriate comparison. Family labor earnings, however, includes earnings of individuals other than the head and spouse. As such, although the tabulations are defined consistently across the
} 
full-time workers), suggesting greater earnings instability for low-income families there than in other countries. The results are quite similar whether the relative poverty threshold or the official U.S. poverty threshold is used. By contrast, government transfers account for relatively large shares of poverty transitions in the other countries, especially exits from poverty in Germany and Great Britain.

On net, the descriptive results presented in this section reveal important differences in poverty dynamics across the four countries, with poverty being relatively persistent in Canada and the United States, relatively infrequent in Germany, and relatively fluid in Great Britain. Explanatory factors such as family structure and job status, and changes therein, generally have similar implications for poverty dynamics in these countries. However, in comparative terms, poverty persistence and transitions are closely related to educational attainment and earnings fluctuations in the United States, family structure in Canada, and government tax and transfer policies in Great Britain and especially Germany.

\section{Regression Analyses of Transitions and Chronic Poverty}

Although the previous section identified and discussed factors that appear to be important determinants of poverty dynamics, the descriptive analyses cannot account for simultaneous occurrence of relevant characteristics and events nor provide an accurate assessment of the magnitude of their impacts. In this section, a quantitative assessment of the impact of simultaneous factors on poverty transitions and persistence is performed

four countries, the contribution of earnings changes to poverty transitions is overstated somewhat relative to the role of changes in full-time work and months worked. 
using a logit regression framework, again focusing on poverty measures based on disposable income (as in the previous sub-section).

The outcomes analyzed are poverty entries, poverty exits, and the incidence of average-income poverty. For entries and exits, the dependent and explanatory variables are all 0-1 dummy variables. As in the descriptive analysis of transitions, the regression sample is formed from the "at-risk" population: poverty entry data points are calculated from the pool of individuals not in poverty, poverty exit data points are calculated from the pool of individuals in poverty, and the observations are pooled over the five pairs of years that span each complete six-year panel. ${ }^{17}$ The explanatory variables include characteristics observed in the base year of each sequential pair of years and changes in characteristics observed between the base year and the next year. The determinants of average-income poverty are analyzed in a similar manner. However, the dependent variable is formed from income during the entire six-year panel; each sample individual contributes only one observation, and the explanatory variables are limited to characteristics observed in the first sample year.

This regression approach captures fewer of the complexities of poverty dynamics than more complicated approaches used in recent analyses that focus on individual countries. For example, in her analysis of PSID data, Stevens (1999) accounted for the role of duration dependence and repeat spells of poverty through the use of a carefully designed discrete hazard model. The six-year panels used here are too short and involve too much censoring of poverty spells for reliable, informative estimation of such models. Nonetheless, the simpler approach used here can yield important insights about covariate

\footnotetext{
${ }^{17}$ The estimated standard errors from the regression are adjusted to account for the dependence across multiple observations per individual.
} 
effects on poverty dynamics. ${ }^{18}$ In conjunction, analyses of poverty transitions and the incidence of average-income poverty can provide useful information for researchers and policy makers, by identifying the impact of characteristics and events that determine poverty experiences and by depicting the population most at risk of chronic poverty.

The results for the poverty transitions and chronic poverty regressions are listed in Tables 8 through 10. In each table, the top row lists the mean value of the dependent variable (in percentage terms). ${ }^{19}$ The explanatory variables are all dummy variables taking on the value 0 or 1 . Their regression effects are expressed in percentage terms relative to the omitted categories listed in the table, based on a straightforward transformation of the fitted probabilities across the entire sample. ${ }^{20}$ The means of the explanatory variables are listed in the column directly to the right of the corresponding coefficients, to help provide a clearer assessment of the relative magnitudes of the covariate effects (for example, events that have a large impact as measured by the

\footnotetext{
${ }^{18}$ The findings of Stevens (1999) for the U.S. and Finnie and Sweetman (2003) for Canada suggest that conditional on other observables, the probability of exiting poverty (duration dependence) is largely flat after about 4 to 6 years.

${ }^{19}$ These means of the entry, exit, and average-income poverty variables differ slightly from those listed in Tables 2 and 3, due to the loss of some observations resulting from missing data on explanatory variables (most frequently hours worked).

20 The regression specification is $y_{i}=F\left(X_{i} \beta\right)$, where $i$ indexes individuals, $y$ is a $0-1$ dependent variable, $X_{i}$ is a vector of explanatory variable values, $\beta$ is a vector of estimated coefficients, and the function $F$ is the logit function. With the subscript $i$ suppressed for notational simplicity, the probability effect of the coefficient $b_{j}$ for element $x_{j}$ of $X$ is calculated by summing over the entire set of observations (of size $\mathrm{N}$ ) as follows:

$\frac{1}{N} \sum\left[F\left(X \beta+\left(1-x_{j}\right) b_{j}\right)-F\left(X \beta-x_{j} b_{j}\right)\right]$

Due to the nonlinearity of the logit model, this calculation yields different results than would the fitted probabilities based on the means of the explanatory variables. For the results displayed in Tables 8-10, the probability effects are obtained as weighted averages using the sampling weights (rather than an unweighted average, which is displayed in the equation above for transparency).
} 
probability effect may be rare and therefore have a small overall impact on the dependent variable). ${ }^{21}$

The results in Table 8 show large effects of various characteristics on the probability of poverty entry. It is informative to compare the coefficients to the mean exit rates listed at the top of the table. For example, individuals in Canadian households characterized by a single adult with children are 3.9 percentage points more likely to enter poverty during a year than are individuals in households with two adults and no children, implying nearly a doubling of the poverty risk relative to the sample base rate of 4.5 percent. More generally, both the impact and incidence of characteristics related to poverty entries are quite similar across the four countries. Among the exceptions are head age: individuals in households with young heads (age<30) face a greater elevation in the risk of poverty entry in Great Britain and the United States than in Canada and Germany. In addition, educational attainment of the family head has a relatively large impact on poverty entries in the United States, consistent with the descriptive results displayed in Figure 2.

Among the events that contribute to poverty entries, in all countries divorce has the largest impact, increasing the entry probability (relative to the sample mean) by a factor of about four to six. ${ }^{22}$ However, the incidence of divorce is low compared with the

\footnotetext{
${ }^{21}$ Due to the non-linearity of the logit model, the product of the probability effect and the variable mean provides an imperfect but relatively consistent comparative indicator of the overall impact of a given explanatory variable on the dependent variable. The exact effects are easily calculated but were omitted to conserve on table space (results available on request to the author).

${ }^{22}$ Using PSID and GSOEP data for the 1980s, Burkhauser et al. (1991) found a larger overall impact of divorce on economic status in Germany than in the United States. The slightly lower impact on poverty entries found here for Germany may be due to differences between American and German social policy or policy changes between the 1980s and 1990s. Moreover, Table 8 indicates that the incidence of divorce in the non-poverty population is lower in Germany than in the United States.
} 
loss of full-time jobs by the family head or spouse, which substantially increases the likelihood of a poverty entry as well; given its impact on poverty entries and its relatively high incidence, the loss of full-time work has the largest impact on poverty entries among all the explanatory variables in each country. ${ }^{23}$ Work instability, as measured by changes in the number of months worked, is more frequent than loss of full-time work but has a much smaller impact on poverty entries, especially in Germany, where its impact is essentially zero.

Many of the results for the poverty exit regressions in Table 9 mirror the entry results in Table 8. Increases in full-time work and months worked by the head and spouse substantially increase the probability of poverty exits; the effects are relatively small for heads in the United States but large for wives. Marriage is a common route out of poverty, except in Germany. Other changes in family structure have little impact on poverty exits, except in Canada, where they increase exits substantially.

Table 9 also contains some surprises regarding the determinants of poverty exits. Individuals in households with young heads experience frequent poverty exits in the United States. Combined with their greater likelihood of entry in Table 8, the results suggest that this group faces substantial income churning around the poverty line in that country. Members of single adult families with children present face low probabilities of poverty exits in Canada and especially the United States (with a statistically insignificant effect in Great Britain). By contrast, such individuals are significantly more likely to exit

\footnotetext{
${ }^{23}$ In the British panel, the share of individuals in households in which neither the head nor spouse works full-time is noticeably higher in Tables 8-10 than it is in the Appendix table. Auxiliary tabulations revealed that this is due to an unusually high proportion of BHPS households in which an individual other than the head or spouse works full time (recall that missing data on hours worked necessitated restriction of the full-time work variable to head and spouse only in the panel analyses and regressions; see footnote 16).
} 
poverty in Germany, perhaps due to a social policy focus on this group. Individuals in families with two workers enjoy high probabilities of poverty exits in Canada and especially the United States, but they face low exit probabilities in Germany, suggesting little upward mobility for two-earner families whose income already places them near the bottom of the income distribution there.

Table 10 displays results for the determinants of average-income (chronic) poverty. The impact of young headship is essentially zero in the United States, consistent with the income churning implied by the transition results in Tables 8 and 9. The educational attainment of household heads has an especially large impact on chronic poverty in the United States: low educational attainment nearly doubles the probability of average-income poverty there. Individuals in single-head families with children face high risks of chronic poverty. This effect is much smaller in Germany than the other countries, however, again suggesting (as in Table 9) that German social policy places substantial emphasis on the well-being of this group. Finally, individuals in families with no full-time workers are especially likely to experience chronic poverty, although the effect is much larger in Canada and the United States than it is in Germany and Great Britain.

To summarize, the regression analyses of poverty transitions and chronic poverty reveal substantial similarities across the four countries, but important differences as well. As expected, both work and marital status have large impacts on poverty status in each country. However, Germany's social welfare system appears to provide substantial antipoverty support for high risk populations, including single parents and their children and individuals facing instability in months (hours) worked. Divorce and marriage are 
commonly associated with poverty transitions; the exception is that marriage is not associated with poverty exits in Germany, perhaps due to extensive public support for single parents there. By contrast, single parents and their children face especially high poverty risks in the United States, where educational attainment is an important poverty determinant as well. Moreover, although full-time work status is important in all four countries, its effects on poverty status_including chronic poverty—are especially large in Canada and the United States

\section{Conclusions}

The analyses in this paper have compared the multi-year poverty experiences of representative panels of individuals in Canada, Germany, Great Britain, and the United States for six years during the 1990s. The results suggest that simple cross-country comparisons of poverty rates at a point in time can mask important underlying variation in the persistence of poverty. Poverty persistence generally increases with relative poverty rates, although this relationship is not uniform; relative to their poverty headcounts, poverty persistence is high in Canada and low in Great Britain. Most poverty transitions, and the incidence of chronic poverty, are associated with employment instability and family dissolution in all four countries, although a substantial share of poverty is found among lower-risk populations as well. Germany's social welfare system appears to provide substantial anti-poverty support to high-risk populations, especially single parents and their children. By contrast, in Canada and especially the United States, single parent families face high risks of prolonged poverty. Educational attainment is crucial in the United States as well, with high poverty persistence evident 
for members of households in which the head's educational attainment is low.

Households with young heads face elevated risks of chronic poverty in Germany and

Great Britain, but in the United States such households face low risks of chronic poverty despite facing high rates of poverty incidence; this finding suggests that income instability falls as families age in the United States.

Regarding policy, the results confirm widely-held beliefs about the key contributions of family stability and work attachment for staying out of poverty in North America and Europe. This suggests important roles for individual behavior as well as public policies that strengthen family stability and work attachment; child care subsidies may be one example of such policies, enabling cash-strapped and time-strapped parents to effectively balance work and home commitments. At the same time, extensive income support and related social policies appear to have the expected effects of reducing overall poverty incidence in Germany and chronic poverty in Great Britain. Policy makers in the United States who are interested in reducing the burden of poverty may wish to examine the policies of those countries more carefully, since in the United States the incidence of working poverty is high and few families are lifted out of poverty through the existing transfer system. Moreover, education plays a critical role in the United States, suggesting that improved student access and commitment to education can serve as an important poverty-reducing mechanism in that country. 


\section{References}

Akerlof, George, and Brian Main. 1981. "An Experience-Weighted of Employment and Unemployment Duration.” American Economic Review 71 (5, December): 10031012.

Bane, Mary Jo, and David Ellwood. 1986. "Slipping Into and Out of Poverty: The Dynamics of Spells." Journal of Human Resources 21 (Winter): 1-23.

Biewen, Martin, and Stephen P. Jenkins. 2002. "Accounting for Poverty Differences between the United States, Great Britain, and Germany." Working Papers of the Institute for Social and Economic Research, paper 2002-14 (September). Colchester: University of Essex. Forthcoming in Empirical Economics.

Blackburn, McKinley. 1998. "The Sensitivity of International Poverty Comparisons.” Review of Income and Wealth 44 (4, Dec.): 449-472.

Blank, Rebecca, and Maria Hanratty. 1993. "Responding to Need: A Comparison of Social Safety Nets in Canada and the United States." In David Card and Richard Freeman, eds., Small Differences that Matter: Labor Markets and Income Maintenance in Canada and the United States (NBER Comparative Labor Market Series). Chicago: University of Chicago Press.

Bradbury, Bruce, Jenkins, Stephen P., and John Micklewright. 2001. “The Dynamics of Child Poverty in Seven Industrialised Nations." In The Dynamics of Child Poverty in Industrialised Countries, edited by Bruce Bradbury, Stephen P. Jenkins, and John Micklewright. Cambridge: Cambridge University Press.

Burkhauser, Richard V. 2001. "Commentary: What Policymakers Need to Know About Poverty Dynamics." Journal of Policy Analysis and Management 20(4): 757760.

Burkhauser, Richard V., Barbara A. Butrica, Mary C. Daly, and Dean R. Lillard. 2001. "The Cross-National Equivalent File: A Product of Cross-National Research." In Soziale Sicherung in einer dynamischen Gesellschaft (Social Insurance in a Dynamic Society), ed. Irene Becker, Notburga Ott, and Gabriele Rolf. Frankfurt and New York: Campus-Verlag.

Burkhauser, Richard V., Greg J. Duncan, Richard Hauser, and Roland Berntsen. 1991. "Wife or Frau, Women do Worse: A Comparison of Men and Women in the United States and Germany After Marital Dissolution.” Demography 28(3): 353360 .

Burkhauser, Richard V., and Timothy M. Smeeding. 2000. "Microdata Panel Data and Public Policy: National and Cross-National Perspectives." Center for Policy Research Working Paper No. 23, Syracuse University, May. 
Clark, Kim B., and Lawrence H. Summers. 1979. "Labor Market Dynamics and Unemployment: A Reconsideration." Brookings Papers on Economic Activity 1:1979: $13-72$.

DiNardo, John, and Thomas Lemieux. 1997. "Diverging Male Wage Inequality in the United States and Canada, 1981-1988: Do Institutions Explain the Difference?" Industrial and Labor Relations Review 50(4): 629-651.

Duncan, Greg J., Björn Gustafsson, Richard Hauser, Günther Schmaus, Hans Messinger, Ruud Muffels, Brian Nolan, and Jean-Claude Ray. 1993. "Poverty dynamics in eight countries." Journal of Population Economics 6: 215-234.

Duncan, Greg J., Björn Gustafsson, Richard Hauser, Günther Schmaus, Stephen Jenkins, Hans Messinger, Ruud Muffels, Brian Nolan, Jean-Claude Ray, and Wolfgang Voges. 1995. "Poverty and Social-Assistance Dynamics in the United States, Canada, and Europe." Chapter 2 in K. McFate, R. Lawson, and W.J. Wilson (eds.), Poverty, Inequality and the Future of Social Policy: Western States in the New Social Order. New York: Russell Sage Foundataion.

Duncan, Greg J., and Willard Rodgers. 1991. "Has Children's Poverty Become More Persistent?" American Sociological Review 56 (Aug.): 538-550.

Finnie, Ross, and Authur Sweetman. 2003. "Poverty dynamics: empirical evidence for Canada." Canadian Journal of Economics 36 (2): 291-325.

Förster, Michael F. 2000. "Trends and Driving Factors in Income Distribution and Poverty in the OECD Area." Labour Market and Social Policy Occasional Papers No. 42, OECD, Paris.

Gottschalk, Peter, and Timothy M. Smeeding. 2000. "Empirical Evidence on Income Inequality in Industrialized Countries." In A.B. Atkinson and F. Bourgignon (eds.), Handbook of Income Distribution. New York: Elsevier-North Holland.

Hill, Martha S., and Stephen P. Jenkins. 2001. "Poverty among British Children: Chronic or Transitory?" In The Dynamics of Child Poverty in Industrialised Countries, edited by Bruce Bradbury, Stephen P. Jenkins, and John Micklewright. Cambridge: Cambridge University Press.

Jäntti, Marcus, and Sheldon Danziger. 2000. "Income Poverty in Advanced Countries." In A.B. Atkinson and F. Bourgignon (eds.), Handbook of Income Distribution. New York: Elsevier-North Holland.

Jenkins, Stephen P., and John Rigg (with the assistance of Francesco Devicienti). 2001. "The Dynamics of Poverty in Britain." Department for Work and Pensions Research Report No. 157, Corporate Document Services, Leeds, December. 
Jenkins, Stephen P., and Christian Schluter. 2003. "Why Are Child Poverty Rates Higher in Britain than in Germany?" Journal of Human Resources 38 (2): 441465.

Lillard, Dean R. (with the assistance of Phillip Giles and Markus M. Grabka). 2004. "Codebook for the Cross-National Equivalent File 1980-2002. BHPS - GSOEP - PSID - SLID.” Mimeo, Department of Policy Analysis and Management, Cornell University.

McFate, Katherine, Roger Lawson, and William Julius Wilson (eds.). 1995. Poverty, Inequality and the Future of Social Policy: Western States in the New Social Order. New York: Russell Sage Foundataion.

OECD. 2001. "When Money is Tight: Poverty Dynamics in OECD Countries." Chapter 2 in OECD Employment Outlook 2001. Paris: OECD.

Osberg, Lars. 2000. "Poverty in Canada and the United States: Measurement, Trends, and Implications." The Canadian Journal of Economics 33 (Nov.): 847-877.

Oxley, Howard, Thai-Thanh Dang, and Pablo Antolín. 2000. "Poverty Dynamics in Six OECD Countries." OECD Economic Studies 30: 7-52.

Rodgers, Joan R., and John L. Rodgers. 1993. "Chronic Poverty in the United States." Journal of Human Resources 28 (1): 25-54.

Ruggles, Patricia. 1990. Drawing the Line: Alternative Poverty Measures and Their Implication for Public Policy. Washington, DC: Urban Institute Press.

Smeeding, Timothy M. 2000. "Changing Income Inequality in OECD Countries: Updated Results from the Luxembourg Income Study (LIS)." Luxembourg Income Study Working Paper No. 252. Syracuse University, March.

Smeeding, Timothy M., Lee Rainwater, and Gary Burtless. 2000. "United States Poverty in a Cross-National Context." Luxembourg Income Study Working Paper No. 244. Syracuse University, September.

Stevens, Ann Huff. 1999. "Climbing Out of Poverty, Falling Back In: Measuring the Persistence of Poverty Over Multiple Spells." Journal of Human Resources 34(3): 557-588. 


\section{Figure 1: Relative risks of short and long-term poverty by family type ${ }^{a}$ (disposable income poverty)}

$\square$ Two adults, children $\square$ Single adult, children

Poor at least once

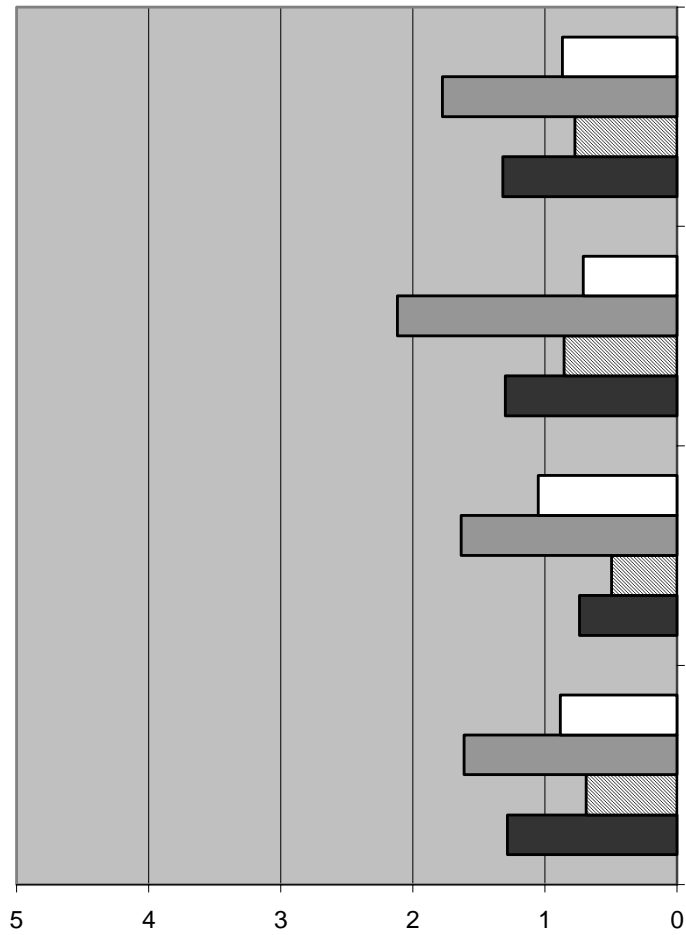

Two adults, no children

Single adult, no children

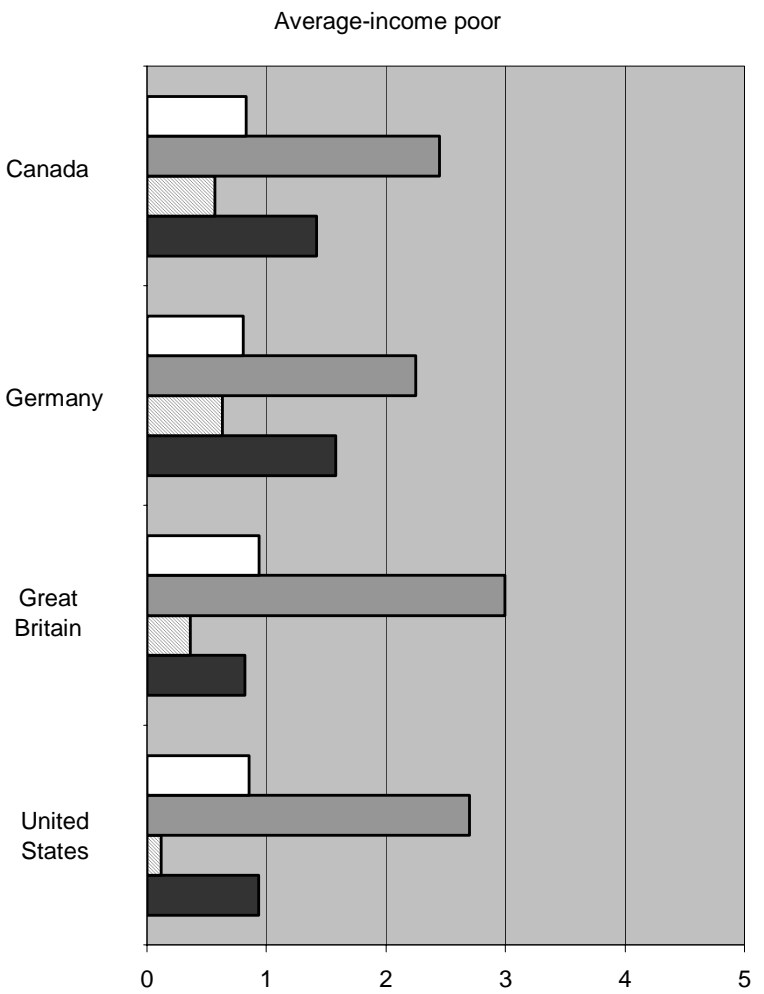

${ }^{\text {a }}$ Ratio of the group's share in poverty against its share in the total population. Note: See Appendix Table A for underlying figures. Refers to six-year period from 1991-1996 (1993-1998 for Canada). Average-income poor is defined by average income compared to the average poverty threshold over the full sample period (see text). Characteristics measured in the first sample year.

Source: SLID for Canada; GSOEP for Germany; BHPS for Great Britain; PSID for the United States (all author's calculations). 
Figure 2: Relative risks of short and long-term poverty, by educational attainment of head ${ }^{a}$

(disposable income poverty)

High

Poor at least once

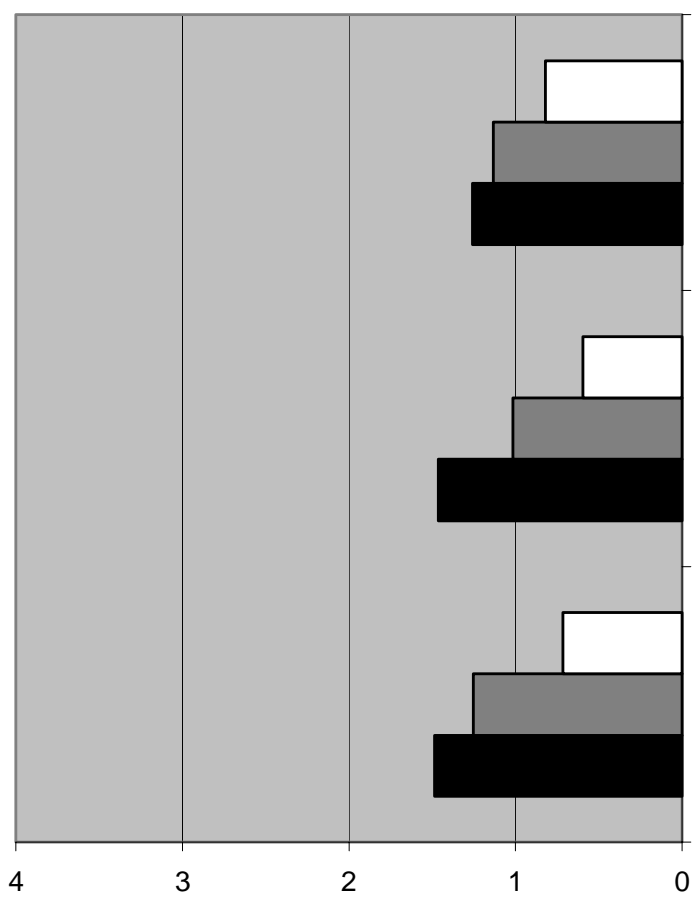

Medium

Low

Average-income poor

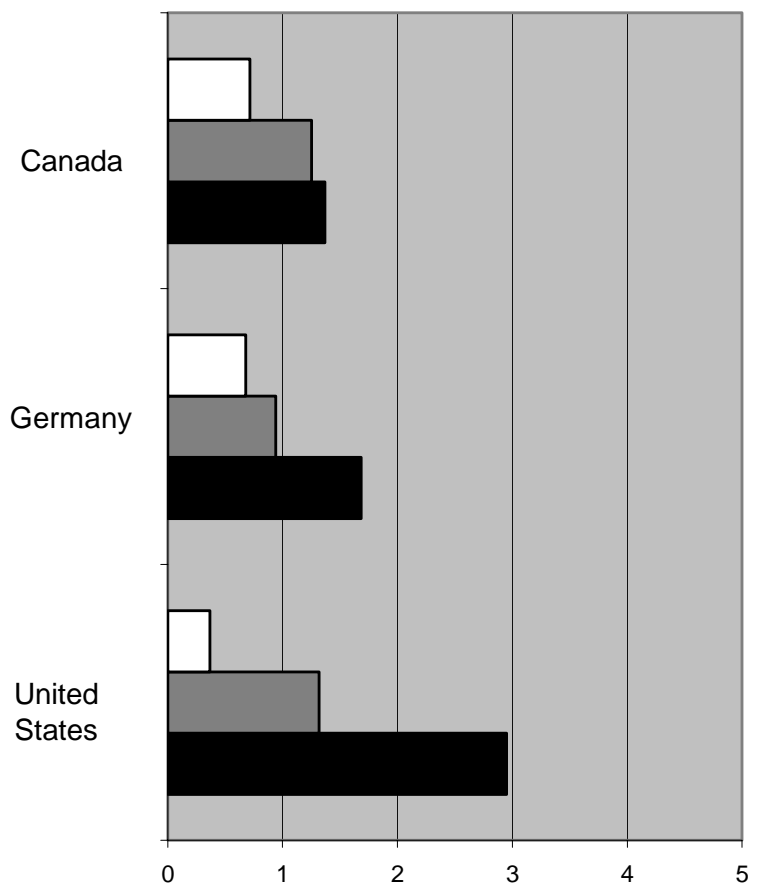

${ }^{\text {a }}$ Ratio of the group's share in poverty against its share in the total population.

Note: See Appendix Table A for underlying figures. Refers to six-year period from 1991-1996 (1993-1998

for Canada). Average-income poor is defined by average income compared to the average poverty threshold over the full sample period (see text). Characteristics measured in the first sample year. Low education is less than upper secondary education, middle is completed upper secondary education, high is tertiary education (data not available for Great Britain).

Source: See Figure 1. 
Figure 3: Relative risks of short and long-term poverty, by family work attachment ${ }^{\mathrm{a}}$

(disposable income poverty)

Two workers

Poor at least once

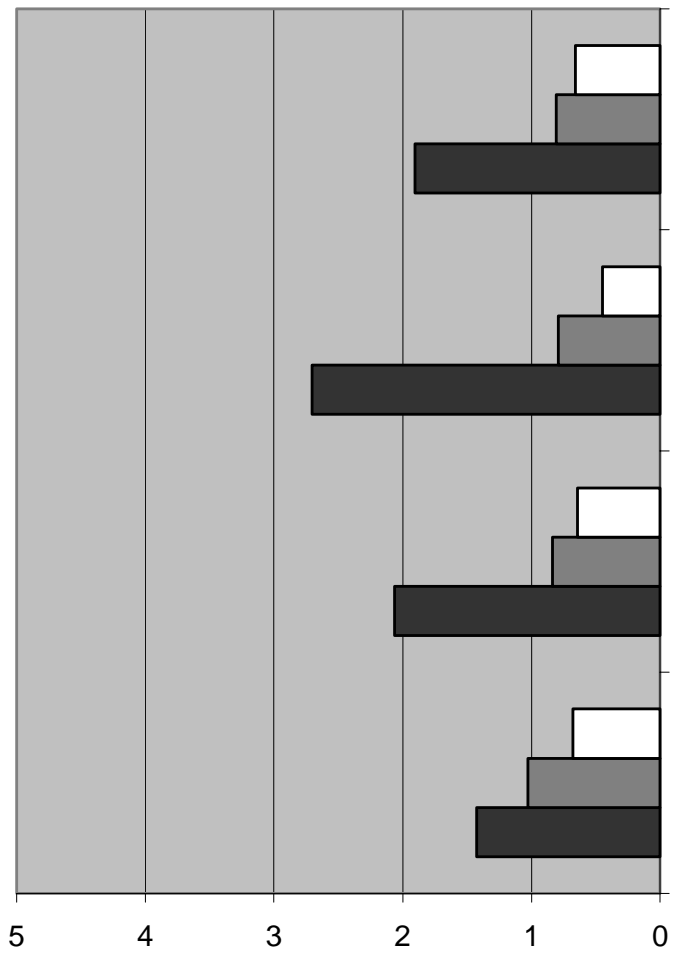

One worker

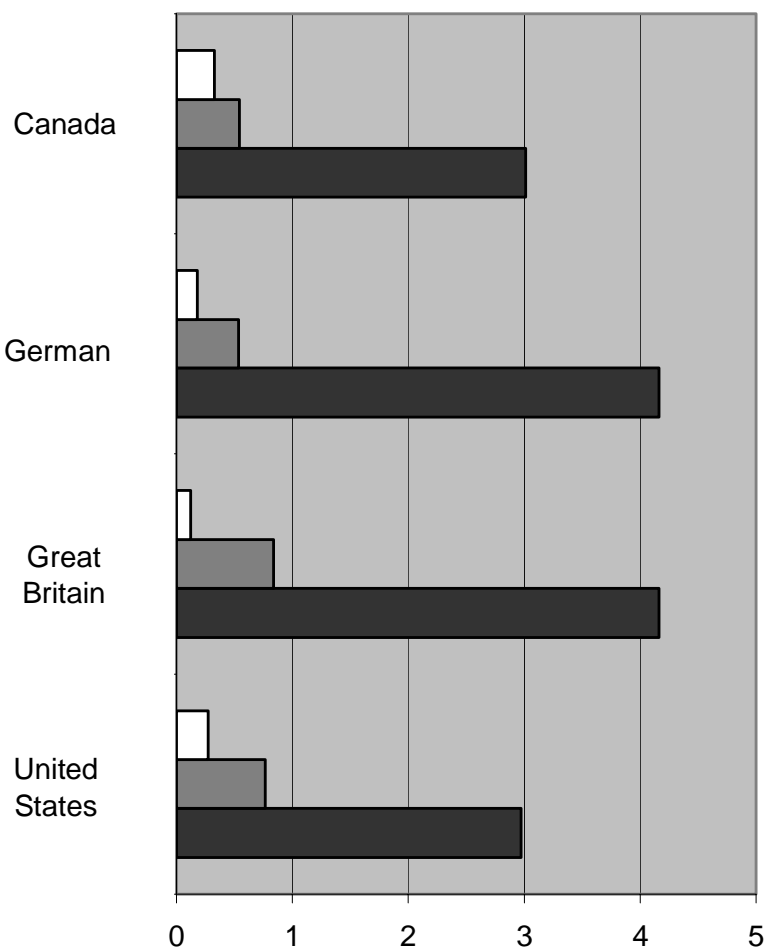

${ }^{\text {a }}$ Ratio of the group's share in poverty against its share in the total population.

Note: See Appendix Table A for underlying figures. Refers to six-year period from 1991-1996 (1993-1998 for Canada). Average-income poor is defined by average income compared to the average poverty threshold over the full sample period (see text). Characteristics measured in the first sample year.

Source: See Figure 1. 


\section{Table 1: Poverty rates and household disposable income statistics}

\begin{tabular}{ccccc} 
& \multicolumn{4}{c}{ Panel A: Canada (1993-1998) } \\
\cline { 2 - 5 } & $\begin{array}{c}\text { Market income } \\
\text { poverty rate }\end{array}$ & $\begin{array}{c}\text { Disposable income } \\
\text { poverty rate }\end{array}$ & $\begin{array}{c}\text { Median income } \\
\text { (disposable) }\end{array}$ & $\begin{array}{c}\text { Standard Deviation } \\
\text { (disposable) }\end{array}$ \\
\cline { 2 - 5 } & \multicolumn{4}{c}{ Percentages } \\
1993 & 19.1 & 11.6 & 42662 & 27016 \\
1994 & 19.4 & 12.7 & 42481 & 27179 \\
1995 & 19.3 & 13.3 & 43220 & 28080 \\
1996 & 19.3 & 43740 & 30570 \\
1997 & 13.8 & 45094 & 33449 \\
1998 & 19.8 & 12.7 & 47119 & 35302 \\
\hline
\end{tabular}

Panel B: Germany (1991-1996)

\begin{tabular}{ccccc} 
& $\begin{array}{c}\text { Market income } \\
\text { Poverty rate }\end{array}$ & $\begin{array}{c}\text { Disposable income } \\
\text { poverty rate }\end{array}$ & $\begin{array}{c}\text { Median income } \\
\text { (disposable) }\end{array}$ & $\begin{array}{c}\text { Standard Deviation } \\
\text { (disposable) }\end{array}$ \\
\cline { 2 - 5 } & \multicolumn{4}{c}{ Percentages } \\
1991 & 14.2 & 8.8 & 45684 & 29800 \\
1992 & 15.2 & 8.9 & 48555 & 30096 \\
1993 & 16.1 & 9.1 & 50422 & 31899 \\
1994 & 17.0 & 9.7 & 50584 & 33247 \\
1995 & 16.8 & 9.3 & 51229 & 32854 \\
1996 & 18.1 & 9.0 & 53161 & 33170 \\
\hline
\end{tabular}

Panel C: Great Britain (1991-1996)

1991

1992

1993

1994

1995

1996

\section{Panel C: Great Britain (1991-1996)}

\begin{tabular}{cccc}
\hline $\begin{array}{c}\text { Market income } \\
\text { Poverty rate }\end{array}$ & $\begin{array}{c}\text { Disposable income } \\
\text { poverty rate }\end{array}$ & $\begin{array}{c}\text { Median income } \\
\text { (disposable) }\end{array}$ & $\begin{array}{c}\text { Standard Deviation } \\
\text { (disposable) }\end{array}$ \\
\hline \multicolumn{3}{c}{ Percentages } \\
\hline 18.8 & 13.8 & 16149 & 11212 \\
20.4 & 13.5 & 16941 & 10466 \\
20.3 & 13.9 & 17502 & 11194 \\
18.6 & 12.0 & 17864 & 13436 \\
18.8 & 13.5 & 18786 & 11663 \\
19.3 & 13.4 & 19409 & 12400 \\
\hline
\end{tabular}

Panel D: United States (1991-1996)

\begin{tabular}{cccc}
\hline $\begin{array}{c}\text { Market income } \\
\text { Poverty rate }\end{array}$ & $\begin{array}{c}\text { Disposable income } \\
\text { poverty rate }\end{array}$ & $\begin{array}{c}\text { Median income } \\
\text { (disposable) }\end{array}$ & $\begin{array}{c}\text { Standard Deviation } \\
\text { (disposable) }\end{array}$ \\
\hline \multicolumn{3}{c}{ Percentages } \\
\hline 17.2 & 16.3 & 31964 & 33000 \\
18.0 & 16.4 & 33093 & 30561 \\
18.8 & 17.3 & 31887 & 37178 \\
17.9 & 17.0 & 33332 & 35817 \\
17.2 & 15.9 & 34584 & 39144 \\
20.8 & 18.9 & 36613 & 38163 \\
\hline
\end{tabular}

Note: Each poverty rate represents the percentage of individuals whose equivalent household income is below $50 \%$ of the median equivalent household disposable income, calculated yearly. Income measured in nominal domestic currencies.

Source: Cross-National Equivalent Files; SLID for Canada, GSOEP for Germany (includes former East Germany for all income years), BHPS for Great Britain, and PSID for the United States (all author's calculations). 
Table 2: Poverty incidence and duration

\begin{tabular}{|c|c|c|c|c|c|}
\hline & $\begin{array}{l}\text { Number of } \\
\text { Individuals }^{\mathrm{a}}\end{array}$ & $\begin{array}{c}\text { Annual } \\
\text { Poverty } \\
\text { Rate }^{\mathrm{b}}\end{array}$ & $\begin{array}{l}\text { In poverty at } \\
\text { least once }\end{array}$ & $\begin{array}{l}\text { Always in } \\
\text { poverty }\end{array}$ & $\begin{array}{l}\text { Average- } \\
\text { income } \\
\text { (chronic) } \\
\text { poverty }^{\mathrm{c}, \mathrm{d}}\end{array}$ \\
\hline & & & Perce & tage & \\
\hline \multicolumn{6}{|l|}{ Canada } \\
\hline Market income & 24093 & 19.5 & 32.7 & 8.0 & $14.5(0.44)$ \\
\hline Disposable income & 24093 & 12.6 & 25.3 & 3.5 & $9.1(0.36)$ \\
\hline \multicolumn{6}{|l|}{ Germany } \\
\hline Market income & 9809 & 16.2 & 27.6 & 3.6 & $9.1(0.33)$ \\
\hline Disposable income & 9809 & 9.1 & 18.1 & 1.4 & $4.4(0.24)$ \\
\hline \multicolumn{6}{|l|}{ Great Britain } \\
\hline Market income & 6436 & 19.4 & 32.5 & 3.1 & $9.7(0.30)$ \\
\hline Disposable income & 6436 & 13.4 & 27.8 & 0.8 & $5.4(0.19)$ \\
\hline \multicolumn{6}{|l|}{ United States } \\
\hline Market income & 6687 & 18.3 & 30.7 & 5.5 & $12.2(0.40)$ \\
\hline Disposable income & 6687 & 17.0 & 30.5 & 3.9 & $10.6(0.35)$ \\
\hline \multicolumn{6}{|l|}{ U.S. (official threshold) } \\
\hline Market income & 6687 & 15.0 & 25.7 & 4.1 & $8.8(0.34)$ \\
\hline Disposable income & 6687 & 11.8 & 22.2 & 2.3 & $6.0(0.27)$ \\
\hline
\end{tabular}

${ }^{a}$ Number of persons present in all six waves of the panel data. The larger number of observations available in the six separate cross-sectional samples was used to calculate annual poverty rates.

${ }^{b}$ Each poverty rate represents the percentage of individuals whose equivalent household income is below $50 \%$ of the median equivalent household disposable income, calculated yearly (unless indicated otherwise). The rate is calculated separately for each sample year and then averaged. ${ }^{c}$ Percentage of the sample for whom average (equivalent) income over the six years falls below the average poverty line over this period (see text).

${ }^{d}$ Figures in parentheses show the ratio of the number of persons in chronic poverty to the number of persons ever poor.

Source: See Table 1. 
Table 3: Transition rates and mean duration

\section{Canada}

Market income

Disposable income

Germany

Market income

Disposable income

Great Britain

Market income

Disposable income

United States

Market income

Disposable income

U.S. (official threshold)

Market income

Disposable income

\begin{tabular}{ccc}
\hline $\begin{array}{c}\text { Annual Poverty } \\
\text { Rate }^{a}\end{array}$ & $\begin{array}{c}\text { Yearly rate of } \\
\text { entry }\end{array}$ & $\begin{array}{c}\text { Yearly rate of } \\
\text { exit }^{c}\end{array}$ \\
\hline \multicolumn{3}{c}{ Percentages } \\
\hline
\end{tabular}

Mean

Duration $^{d}$

19.5

12.6

5.1

4.5

24.4

31.9

3.1

2.6

16.2

4.9

26.9

42.0

2.4

9.1

3.1

35.0

50.1

2.2

13.4

5.6

5.1

5.3

5.5

31.4

37.3

2.3

17.0

4.3

3.9

32.8

41.7

2.3

11.8

${ }^{a}$ Each poverty rate represents the percentage of individuals whose equivalent household income is below $50 \%$ of the median equivalent household disposable income, calculated yearly (unless indicated otherwise). The rate is calculated separately for each sample year and then averaged.

${ }^{b}$ Number of persons entering poverty between $t$ and $t+1$, as a share of the population not in poverty in t, averaged over the period.

${ }^{c}$ Number of poor in $t$ who exit poverty in $t+1$, as a share of the population in poverty in $t$, averaged over the period.

${ }^{d}$ Average length of observed (censored) poverty spells, in years.

Source: See Table 1. 
Table 4: Poverty spell durations for persons ever poor

\begin{tabular}{|c|c|c|c|c|c|c|c|}
\hline & \multirow{2}{*}{$\begin{array}{c}\text { Annual } \\
\text { Poverty } \\
\text { Rate }^{\mathrm{a}}\end{array}$} & \multicolumn{3}{|c|}{ Share of poverty spells lasting: } & \multicolumn{3}{|c|}{$\begin{array}{l}\text { Share of total years in poverty } \\
\text { for spells lasting: }\end{array}$} \\
\hline & & $\begin{array}{c}1-2 \\
\text { years }\end{array}$ & 3-4 years & $5-6$ years & $\begin{array}{c}1-2 \\
\text { years }\end{array}$ & $3-4$ years & 5-6 years \\
\hline \multicolumn{8}{|l|}{ Canada } \\
\hline Market income & 19.5 & 72.5 & 14.0 & 13.5 & 27.8 & 20.6 & 51.6 \\
\hline Disposable income & 12.6 & 77.7 & 14.0 & 8.3 & 37.6 & 24.8 & 37.6 \\
\hline \multicolumn{8}{|l|}{ Germany } \\
\hline Market income & 16.2 & 65.1 & 19.0 & 15.9 & 35.2 & 27.0 & 37.9 \\
\hline Disposable income & 9.1 & 76.5 & 14.5 & 9.1 & 48.0 & 25.3 & 26.7 \\
\hline \multicolumn{8}{|l|}{ Great Britain } \\
\hline Market income & 19.4 & 69.1 & 18.1 & 12.7 & 40.0 & 27.7 & 32.3 \\
\hline Disposable income & 13.4 & 80.8 & 14.6 & 4.6 & 57.7 & 27.5 & 14.8 \\
\hline \multicolumn{8}{|l|}{ United States } \\
\hline Market income & 18.3 & 68.5 & 14.1 & 17.4 & 34.9 & 20.0 & 45.1 \\
\hline Disposable income & 17.0 & 73.0 & 13.7 & 13.3 & 41.7 & 21.1 & 37.2 \\
\hline \multicolumn{8}{|l|}{ U.S. (official threshold) } \\
\hline Market income & 15.0 & 69.3 & 14.0 & 16.8 & 36.7 & 20.0 & 43.3 \\
\hline Disposable income & 11.8 & 75.7 & 13.2 & 11.0 & 45.6 & 22.3 & 32.1 \\
\hline
\end{tabular}

${ }^{a}$ Each poverty rate represents the percentage of individuals whose equivalent household income is below $50 \%$ of the median equivalent household disposable income, calculated yearly (unless indicated otherwise). The rate is calculated separately for each sample year and then averaged.

Source: See Table 1. 
Table 5: Frequency of family-related events associated with poverty transitions (disposable income poverty)

Entries

\begin{tabular}{|c|c|c|c|c|c|c|c|c|}
\hline & \multicolumn{8}{|c|}{ Percentage associated with: } \\
\hline & $\begin{array}{l}\text { Number of } \\
\text { Observations }\end{array}$ & $\begin{array}{c}\text { Change in } \\
\text { family } \\
\text { structure }^{\mathrm{a}}\end{array}$ & $\begin{array}{l}\text { New } \\
\text { born } \\
\text { child }\end{array}$ & $\begin{array}{c}\text { More } \\
\text { members } \\
\text { in family }\end{array}$ & $\begin{array}{c}\text { Less } \\
\text { members } \\
\text { in family }\end{array}$ & $\begin{array}{l}\text { Separation } \\
\text { / divorce }^{\mathrm{e}}\end{array}$ & $\begin{array}{l}\text { Newly } \\
\text { established } \\
\text { family }^{f}\end{array}$ & $\begin{array}{l}\text { Other } \\
\text { changes }\end{array}$ \\
\hline Canada & 4930 & 46.6 & 5.9 & 1.0 & 5.8 & 10.4 & 14.6 & 8.8 \\
\hline Germany & 1327 & 40.4 & 3.4 & 2.7 & 6.3 & 16.6 & 9.5 & 1.9 \\
\hline $\begin{array}{l}\text { Great } \\
\text { Britain }\end{array}$ & 1438 & 38.3 & 7.2 & 1.0 & 6.7 & 7.2 & 8.5 & 7.8 \\
\hline $\begin{array}{l}\text { United } \\
\text { States }\end{array}$ & 1786 & 37.4 & 6.1 & 4.3 & 4.3 & 14.7 & 4.9 & 3.2 \\
\hline
\end{tabular}

Exits

\begin{tabular}{|c|c|c|c|c|c|c|c|c|}
\hline & \multicolumn{8}{|c|}{ Percentage associated with: } \\
\hline & $\begin{array}{l}\text { Number of } \\
\text { Observations }\end{array}$ & $\begin{array}{c}\text { Change in } \\
\text { family } \\
\text { structure }^{\mathrm{a}}\end{array}$ & $\begin{array}{l}\text { New } \\
\text { born } \\
\text { child }^{\mathrm{b}}\end{array}$ & $\begin{array}{c}\text { More } \\
\text { members } \\
\text { in family }\end{array}$ & $\begin{array}{c}\text { Less } \\
\text { members } \\
\text { in family }\end{array}$ & Marriage $^{\mathrm{g}}$ & $\begin{array}{c}\text { Newly } \\
\text { established } \\
\text { family }\end{array}$ & $\begin{array}{l}\text { Other } \\
\text { changes }\end{array}$ \\
\hline Canada & 4877 & 38.2 & 2.8 & 4.3 & 5.2 & 12.3 & 2.4 & 11.3 \\
\hline Germany & 1348 & 24.0 & 1.5 & 7.4 & 3.1 & 10.7 & 0.4 & 0.9 \\
\hline $\begin{array}{l}\text { Great } \\
\text { Britain }\end{array}$ & 1572 & 29.8 & 4.2 & 2.9 & 3.3 & 9.8 & 0.8 & 8.9 \\
\hline $\begin{array}{l}\text { United } \\
\text { States }\end{array}$ & 1946 & 27.2 & 2.3 & 3.3 & 7.2 & 8.5 & 1.0 & 5.0 \\
\hline
\end{tabular}

${ }^{a}$ For any of the listed reasons.

${ }^{b}$ No split, no change in marital status, same head, more children.

${ }^{c}$ No split, no change in marital status, same head, more members (same number or fewer children).

${ }^{d}$ No split, no change in marital status, same head, fewer members.

${ }^{e}$ There is a spouse/partner (woman) in $\mathrm{t}-1$ and not in $\mathrm{t}$.

${ }^{f}$ Split of household and a child/other relative becomes head or spouse.

${ }^{g}$ There is a spouse/partner in the household in $t$ and not in $\mathrm{t}-1$.

Sources: See Table 1. 
Table 6: Frequency of job-related events associated with poverty transitions (disposable income poverty)

Entries

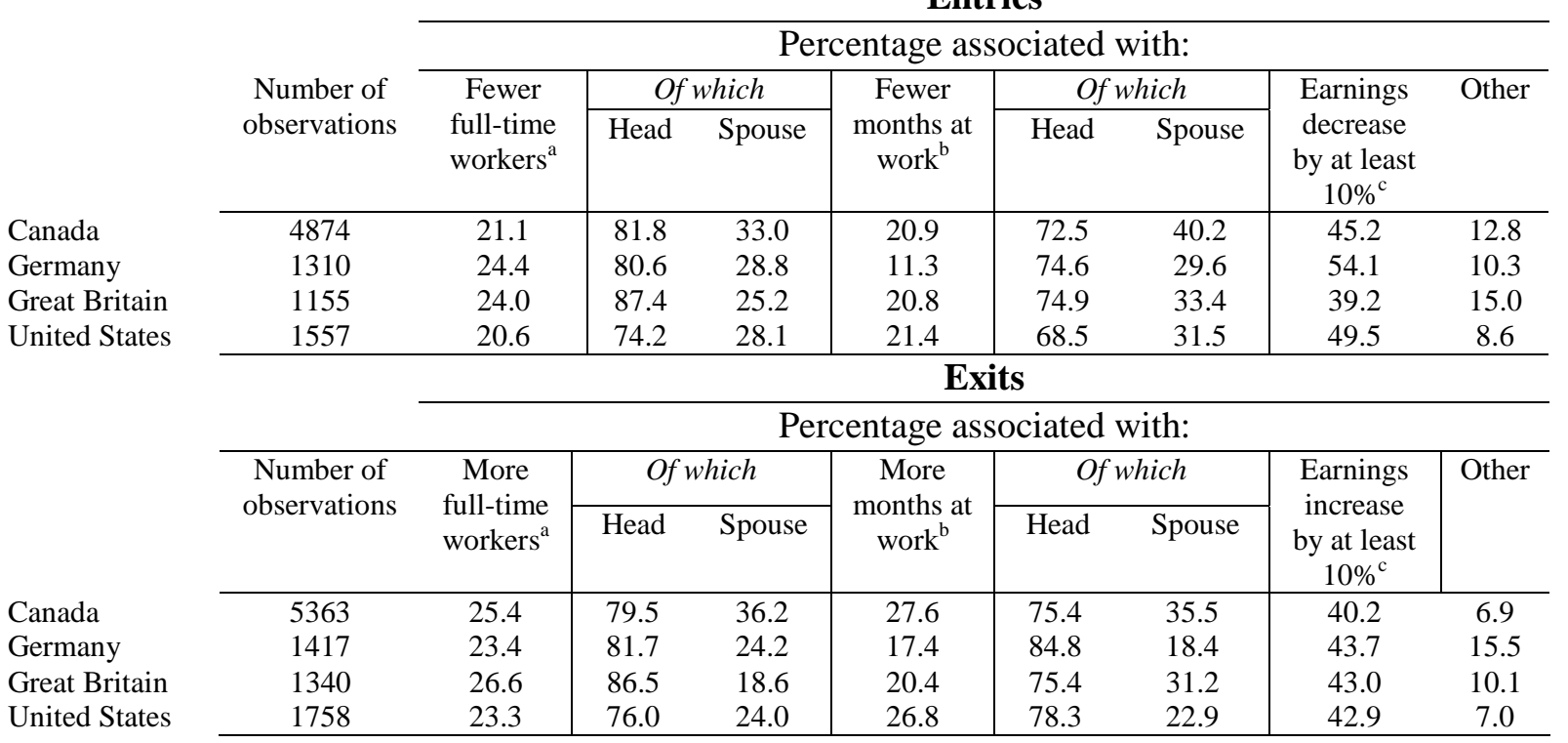

${ }^{a}$ Full time defined as at least 1750 hours per year (head and spouse only).

${ }^{b}$ No change in the number of workers. Defined as annual hours worked having changed at least 160 in the indicated direction (head and spouse only).

${ }^{c}$ No change in head and spouse full-time work or months worked (includes earnings changes for other household members).

Sources: See Table 1. 
Table 7: Frequency of family and job-related events associated with poverty transitions (disposable income poverty)

\begin{tabular}{|c|c|c|c|c|c|c|c|}
\hline \multirow[b]{5}{*}{ Canada } & \multirow{4}{*}{$\begin{array}{l}\text { Number of } \\
\text { observations }\end{array}$} & \multicolumn{6}{|c|}{ Entries } \\
\hline & & \multicolumn{6}{|c|}{ Percentage of total entries associated with: } \\
\hline & & \multirow{2}{*}{$\begin{array}{l}\text { Change in } \\
\text { family } \\
\text { structure }\end{array}$} & \multirow{2}{*}{$\begin{array}{l}\text { Fewer } \\
\text { full-time } \\
\text { workers }^{\mathrm{a}}\end{array}$} & \multicolumn{3}{|c|}{ Largest decrease in } & \multirow[b]{2}{*}{ Other } \\
\hline & & & & Earnings $^{\mathrm{b}}$ & Transfers ${ }^{\mathrm{b}}$ & $\begin{array}{l}\text { Capital and } \\
\text { other income }^{\text {b }}\end{array}$ & \\
\hline & 4874 & 46.9 & 6.4 & 27.3 & 13.3 & 6.0 & 0.2 \\
\hline Germany & 1310 & 38.8 & 10.4 & 31.1 & 14.5 & 5.0 & 0.3 \\
\hline Great Britain & 1155 & 42.3 & 11.0 & 32.5 & 10.5 & 3.4 & 0.4 \\
\hline United States & 1557 & 39.0 & 10.4 & 40.9 & 4.0 & 5.2 & 0.5 \\
\hline \multirow{5}{*}{$\begin{array}{l}\text { U.S. (official } \\
\text { threshold) }\end{array}$} & 1155 & 39.5 & 9.4 & 40.8 & 4.4 & 5.7 & 0.3 \\
\hline & \multirow{4}{*}{$\begin{array}{l}\text { Number of } \\
\text { observations }\end{array}$} & \multicolumn{6}{|c|}{ Exits } \\
\hline & & \multicolumn{6}{|c|}{ Percentage of total exits associated with: } \\
\hline & & \multirow{2}{*}{$\begin{array}{c}\text { Change in } \\
\text { family } \\
\text { structure }\end{array}$} & \multirow{2}{*}{$\begin{array}{c}\text { More } \\
\text { full-time } \\
\text { workers }^{\text {a }}\end{array}$} & \multicolumn{3}{|c|}{ Largest increase in } & \multirow[b]{2}{*}{ Other } \\
\hline & & & & Earnings $^{\mathrm{b}}$ & Transfers $^{\mathrm{b}}$ & $\begin{array}{c}\text { Capital and } \\
\text { other income }\end{array}$ & \\
\hline Canada & 5363 & 39.1 & 15.8 & 28.3 & 11.5 & 5.2 & 0.1 \\
\hline Germany & 1417 & 24.4 & 14.2 & 32.2 & 24.2 & 4.7 & 0.3 \\
\hline Great Britain & 1340 & 32.0 & 17.6 & 28.9 & 17.2 & 3.9 & 0.5 \\
\hline United States & 1758 & 29.3 & 16.4 & 42.8 & 5.3 & 5.5 & 0.7 \\
\hline $\begin{array}{l}\text { U.S. (official } \\
\text { threshold) }\end{array}$ & 1327 & 30.0 & 16.1 & 42.6 & 5.3 & 5.7 & 0.3 \\
\hline
\end{tabular}

${ }^{a}$ No change in family structure. Full time defined as at least 1750 hours per year (head and spouse only).

${ }^{b}$ No change in family structure or in full-time work by the head and spouse.

Sources: See Table 1. 
Table 8: Determinants of Poverty Entries

(disposable income poverty)

\begin{tabular}{|c|c|c|c|c|c|c|c|c|}
\hline \multirow[b]{3}{*}{ Explanatory Variables } & \multirow{2}{*}{\multicolumn{2}{|c|}{$\begin{array}{c}\text { Canada } \\
(1994-1998)\end{array}$}} & \multicolumn{2}{|c|}{$\begin{array}{c}\text { Germany } \\
(1992-1996)\end{array}$} & \multirow{2}{*}{\multicolumn{2}{|c|}{$\begin{array}{c}\text { Great Britain } \\
(1992-1996)\end{array}$}} & \multicolumn{2}{|c|}{$\begin{array}{c}\text { United States } \\
(1992-1996)\end{array}$} \\
\hline & & & \multicolumn{2}{|c|}{2.6} & & & \multicolumn{2}{|c|}{4.9} \\
\hline & $\begin{array}{c}\text { Probability } \\
\text { Effect }\end{array}$ & Mean & Probability Effec & Mean & $\begin{array}{c}\text { Probability } \\
\text { Effect }\end{array}$ & Mean & $\begin{array}{c}\text { Probability } \\
\text { Effect }\end{array}$ & Mean \\
\hline \multicolumn{9}{|l|}{ Head Age (omitted = age 30-50) } \\
\hline Head $<30$ & $0.9 * *$ & 14.3 & $1.3 * *$ & 13.4 & $2.3 * *$ & 12.8 & $2.5^{* *}$ & 14.9 \\
\hline Head 51-65 & $-0.6^{* *}$ & 17.2 & $-1.1 * *$ & 28.1 & $-1.5 * *$ & 22.9 & 0.3 & 14.9 \\
\hline \multicolumn{9}{|l|}{ Head Education (omitted = HS grad) } \\
\hline Low Education & $0.5^{*}$ & 18.5 & $0.8 * *$ & 13.9 & N/A & N/A & $3.9 * *$ & 6.9 \\
\hline High Education & $-1.2 * *$ & 54.1 & $-1.5 * *$ & 21.6 & N/A & N/A & $-3.4 * *$ & 56.4 \\
\hline \multicolumn{9}{|l|}{ Individual Age (omitted = adult) } \\
\hline Child & $0.9 * *$ & 25.8 & $1.1 * *$ & 20.7 & $1.4 * *$ & 23.6 & $1.1 * *$ & 26.9 \\
\hline \multicolumn{9}{|l|}{ Family Type (omitted $=2$ adults w/kids) } \\
\hline Single Adult & $1.9 * *$ & 5.9 & $1.8 * *$ & 10.4 & 0.5 & 5.2 & $2.2 * *$ & 11.5 \\
\hline Adults no Kids & $-0.5^{*}$ & 13.7 & $0.9 * *$ & 14.6 & $-1.1 *$ & 19.0 & $-2.3^{* *}$ & 15.4 \\
\hline Single with Kids & $3.9 * *$ & 8.3 & $2.2 * *$ & 7.9 & $5.3 * *$ & 6.7 & $5.8^{* *}$ & 10.0 \\
\hline Other Family Type & $0.7 *$ & 6.2 & -0.2 & 4.0 & $1.8^{*}$ & 2.4 & 0.5 & 2.3 \\
\hline \multicolumn{9}{|l|}{ Number of Workers (omitted $=1$ worker) ${ }^{\mathrm{a}}$} \\
\hline No Workers & $7.2 * *$ & 21.9 & $6.9 * *$ & 17.0 & $6.2^{* *}$ & 27.4 & $6.0^{* *}$ & 10.8 \\
\hline Two Workers & $-2.7 * *$ & 22.9 & $-2.6 * *$ & 16.4 & $-3.5 * *$ & 19.9 & $-2.7 * *$ & 31.1 \\
\hline \multicolumn{9}{|l|}{ Decline in full-time work ${ }^{\mathrm{b}}$} \\
\hline Less Work - Head & $10.2 * *$ & 7.2 & $8.2 * *$ & 7.3 & $11.6 * *$ & 9.2 & $8.3^{* *}$ & 5.8 \\
\hline Less Work - Spouse & $5.5 * *$ & 6.4 & $5.7 * *$ & 4.5 & $6.6 * *$ & 5.6 & $6.2 * *$ & 4.8 \\
\hline \multicolumn{9}{|l|}{ Decline in months worked ${ }^{c}$} \\
\hline Fewer months - Head & $2.7 * *$ & 15.1 & 0.0 & 13.8 & $2.6 * *$ & 14.6 & $1.0^{*}$ & 13.0 \\
\hline Fewer months - Spouse & $2.4 * *$ & 11.1 & $-0.6 *$ & 9.3 & $3.0 * *$ & 8.2 & $1.8^{* *}$ & 7.4 \\
\hline \multicolumn{9}{|l|}{ Change in family status } \\
\hline Divorce & $15.0 * *$ & 3.5 & $17.9 * *$ & 2.0 & $17.5 * *$ & 2.8 & $22.6^{* *}$ & 3.3 \\
\hline Other Family Change & $2.0 * *$ & 7.1 & $0.9 *$ & 0.5 & -0.2 & 6.3 & 0.7 & 8.1 \\
\hline Log-likelihood & -14935.5 & & -3841.5 & & -3901.2 & & -4588.7 & \\
\hline Number of Observations & 98775 & & 41260 & & 26887 & & 24753 & \\
\hline
\end{tabular}

Note: Based on logit regression results. All variable means and coefficient effects expressed as percentages (see text).

"*” and "**" indicate that the associated regression coefficient is significant at the $5 \%$ level or $1 \%$ level, respectively. "N/A" indicates the variables are not available in the given sample. Regressions account for dependence of multiple observations per sample individual.

${ }^{a}$ Refers to full-time work, defined as at least 1750 hours per year (head and spouse only).

${ }^{\mathrm{b}}$ Head and spouse only.

${ }^{c}$ Defined as a decline of at least 160 annual hours worked (head and spouse total).

Sources: See Table 1. 
Table 9: Determinants of Poverty Exits (disposable income poverty)

\begin{tabular}{|c|c|c|c|c|c|c|c|c|}
\hline \multirow{3}{*}{ Exit Rate (\%) } & \multirow{2}{*}{\multicolumn{2}{|c|}{$\begin{array}{c}\text { Canada } \\
(1994-1998)\end{array}$}} & \multirow{2}{*}{\multicolumn{2}{|c|}{$\begin{array}{c}\begin{array}{c}\text { Germany } \\
(1992-1996)\end{array} \\
46.3\end{array}$}} & \multirow{2}{*}{\multicolumn{2}{|c|}{$\begin{array}{c}\begin{array}{c}\text { Great Britain } \\
(1992-1996)\end{array} \\
50.3\end{array}$}} & \multirow{2}{*}{\multicolumn{2}{|c|}{$\begin{array}{c}\begin{array}{c}\text { United States } \\
(1992-1996)\end{array} \\
40.1\end{array}$}} \\
\hline & & & & & & & & \\
\hline & $\begin{array}{c}\text { Probability } \\
\text { Effect }\end{array}$ & Mean & $\begin{array}{c}\text { Probability } \\
\text { Effect }\end{array}$ & Mean & $\begin{array}{c}\text { Probability } \\
\text { Effect }\end{array}$ & Mean & $\begin{array}{c}\text { Probability } \\
\text { Effect }\end{array}$ & Mean \\
\hline \multicolumn{9}{|l|}{ Head Age (omitted = age 30-50) } \\
\hline Head $<30$ & 1.4 & 28.8 & $-7.8 * *$ & 31.8 & $-4.9 *$ & 25.7 & $7.2 * *$ & 30.4 \\
\hline Head 51-65 & -1.5 & 14.0 & $-8.2 * *$ & 27.4 & -0.9 & 10.7 & $11.7 * *$ & 8.5 \\
\hline \multicolumn{9}{|l|}{ Head Education (omitted = HS grad) } \\
\hline Low Education & -1.7 & 35.3 & 1.0 & 23.0 & N/A & N/A & $-11.3 * *$ & 28.5 \\
\hline High Education & $5.1 * *$ & 30.8 & 0.2 & 9.8 & N/A & N/A & $14.7 * *$ & 22.7 \\
\hline \multicolumn{9}{|l|}{ Individual Age (omitted = adult) } \\
\hline Child & $-2.2 *$ & 30.8 & -0.9 & 23.2 & -4.1 & 37.2 & $-3.3 *$ & 39.4 \\
\hline \multicolumn{9}{|l|}{ Family Type (omitted $=2$ adults $\mathrm{w} /$ kids) } \\
\hline Single Adult & -2.0 & 16.8 & 2.6 & 25.1 & $-7.9 *$ & 11.5 & $-8.1 * *$ & 12.8 \\
\hline Adults no Kids & $5.8 * *$ & 6.5 & 8.6 & 10.6 & -2.6 & 6.5 & $10.1 *$ & 3.3 \\
\hline Single with Kids & $-3.0 * *$ & 29.5 & $8.1 * *$ & 29.1 & -3.1 & 23.9 & $-10.4 * *$ & 52.4 \\
\hline Other Family Type & 0.2 & 5.0 & $16.4^{* *}$ & 9.1 & $16.5 *$ & 3.2 & 6.0 & 2.8 \\
\hline \multicolumn{9}{|l|}{ Number of Workers $(\text { omitted }=1 \text { worker })^{\mathrm{a}}$} \\
\hline No Workers & $-13.8 * *$ & 75.1 & $-6.5 *$ & 76.7 & $-12.1 * *$ & 71.9 & $-18.5 * *$ & 59.7 \\
\hline Two Workers & $6.4 * *$ & 3.0 & $-19.6 * *$ & 2.5 & -4.4 & 1.3 & $14.2 * *$ & 4.1 \\
\hline \multicolumn{9}{|l|}{ Increase in full-time work ${ }^{b}$} \\
\hline More Work - Head & $31.9 * *$ & 11.6 & $39.6 * *$ & 10.0 & $31.7 * *$ & 16.7 & $24.7 * *$ & 13.3 \\
\hline More Work - Spouse & $22.5 * *$ & 5.2 & $33.3 * *$ & 3.3 & $26.7 * *$ & 2.6 & $39.2 * *$ & 3.3 \\
\hline \multicolumn{9}{|l|}{ Increase in months worked ${ }^{c}$} \\
\hline More Hours - Head & $12.1 * *$ & 19.1 & $11.3 * *$ & 15.2 & $5.5 *$ & 17.9 & $5.0 * *$ & 20.9 \\
\hline More Hours - Spouse & $9.8 * *$ & 10.7 & $14.6 * *$ & 4.3 & $8.5 *$ & 8.9 & $23.2 * *$ & 6.4 \\
\hline \multicolumn{9}{|l|}{ Change in family type } \\
\hline Marriage & $39.9 * *$ & 5.4 & 9.9 & 6.3 & $45.9 * *$ & 5.6 & $34.3 * *$ & 5.0 \\
\hline Other Family Change & $15.7 * *$ & 9.9 & -3.6 & 8.2 & -3.4 & 7.0 & -0.4 & 13.6 \\
\hline Log-likelihood & -7438.5 & & -1415.0 & & -1606.1 & & -2439.9 & \\
\hline Number of Observations & 13795 & & 2230 & & 2570 & & 4454 & \\
\hline
\end{tabular}

Note: Based on logit regression results. All variable means and coefficient effects expressed as percentages (see text).

"*" and "**" indicate that the associated regression coefficient is significant at the $5 \%$ level or $1 \%$ level, respectively. "N/A" indicates the variables are not available in the given sample. Regressions account for non-independence of multiple observations per sample individual.

${ }^{a}$ Refers to full-time work, defined as at least 1750 hours per year (head and spouse only).

${ }^{\mathrm{b}}$ Head and spouse only.

${ }^{c}$ Defined as an increase of at least 160 annual hours worked (head and spouse total).

Sources: See Table 1. 
Table 10: Determinants of Average-Income Poverty (disposable income)

\begin{tabular}{|c|c|c|c|c|c|c|c|c|}
\hline & \multicolumn{2}{|c|}{$\begin{array}{c}\text { Canada } \\
(1994-1998)\end{array}$} & \multicolumn{2}{|c|}{$\begin{array}{c}\text { Germany } \\
(1992-1996)\end{array}$} & \multicolumn{2}{|c|}{$\begin{array}{l}\text { Great Britain } \\
(1992-1996)\end{array}$} & \multicolumn{2}{|c|}{$\begin{array}{l}\text { United States } \\
(1992-1996)\end{array}$} \\
\hline Average-Income Poverty Rate (\%) & \multicolumn{2}{|c|}{9.1} & \multicolumn{2}{|c|}{3.8} & \multicolumn{2}{|c|}{5.4} & \multicolumn{2}{|c|}{10.6} \\
\hline Explanatory Variables & $\begin{array}{c}\text { Probability } \\
\text { Effect }\end{array}$ & Mean & Probability Effe & Mean & $\begin{array}{c}\text { Probability } \\
\text { Effect }\end{array}$ & Mean & $\begin{array}{c}\text { Probability } \\
\text { Effect }\end{array}$ & Mean \\
\hline \multicolumn{9}{|l|}{ Head Age (omitted = age 30-50) } \\
\hline Head $<30$ & $1.9 * *$ & 16.5 & $2.2 * *$ & 16.6 & $2.9 * *$ & 15.9 & 1.2 & 19.3 \\
\hline Head 51-65 & 0.1 & 14.8 & 0.2 & 24.5 & -1.0 & 17.3 & -0.2 & 13.7 \\
\hline \multicolumn{9}{|l|}{ Head Education (omitted = HS grad) } \\
\hline Low Education & $2.8 * *$ & 21.3 & $1.6 * *$ & 15.1 & N/A & N/A & $9.5 * *$ & 10.9 \\
\hline High Education & $-3.5 * *$ & 50.6 & -0.5 & 20.2 & N/A & N/A & $-10.6 * *$ & 51.6 \\
\hline \multicolumn{9}{|l|}{ Individual Age (omitted = adult) } \\
\hline Child & $3.6^{* *}$ & 28.9 & $1.2 *$ & 22.8 & $2.0 * *$ & 28.4 & $1.9 * *$ & 30.2 \\
\hline \multicolumn{9}{|l|}{ Family Type (omitted $=2$ adults $\mathrm{w} / \mathrm{kids}$ ) } \\
\hline Single Adult & $6.8 * *$ & 6.2 & $2.8 * *$ & 11.4 & 0.7 & 4.7 & -0.5 & 10.8 \\
\hline Adults no Kids & -0.8 & 11.7 & 0.9 & 12.8 & -1.4 & 16.4 & $-7.5 * *$ & 13.8 \\
\hline Single with Kids & $7.6 * *$ & 10.1 & $2.3 * *$ & 9.2 & $5.6 * *$ & 7.9 & $9.1 * *$ & 13.3 \\
\hline Other Family Type & $-2.2 *$ & 5.1 & 0.5 & 3.6 & $-3.4 *$ & 2.5 & -4.3 & 1.5 \\
\hline \multicolumn{9}{|l|}{ Number of Workers $(\text { omitted }=1 \text { worker })^{\mathrm{a}}$} \\
\hline No Workers & $15.3 * *$ & 22.6 & $6.5 * *$ & 15.0 & $5.2 * *$ & 25.7 & $16.9 * *$ & 16.9 \\
\hline Two Workers & $-4.1 * *$ & 21.9 & $-2.2 * *$ & 21.3 & $-4.0 * *$ & 20.1 & $-6.9 * *$ & 25.6 \\
\hline Log-likelihood & -5305.8 & & -1048.4 & & -934.1 & & -1704.8 & \\
\hline Number of Observations & 21463 & & 9626 & & 5867 & & 6687 & \\
\hline
\end{tabular}

Note: Based on logit regression results. All variable means and coefficient effects expressed as percentages (see text).

"*” and "**" indicate that the associated regression coefficient is significant at the 5\% level or $1 \%$ level, respectively. "N/A" indicates the variables are not available in the given sample.

${ }^{a}$ Refers to full-time work, defined as at least 1750 hours per year (head and spouse only).

Sources: See Table 1. 
Appendix Table A. Characteristics of the non-poor, short-term poor, and longer-term poor, 1991-1996 (disposable income poverty; percentage shares by category)

\begin{tabular}{|c|c|c|c|c|c|c|c|c|c|c|c|}
\hline \multirow{2}{*}{\multicolumn{2}{|c|}{ Household Characteristic ${ }^{\mathrm{a}}$}} & \multicolumn{5}{|c|}{ Canada (1993-1998) } & \multicolumn{5}{|c|}{ Germany } \\
\hline & & \multirow{2}{*}{$\begin{array}{c}\begin{array}{c}\text { Total } \\
\text { Population }\end{array} \\
87.7\end{array}$} & \multirow{2}{*}{$\begin{array}{c}\text { Non- } \\
\text { poor }\end{array}$} & \multirow{2}{*}{$\begin{array}{c}\begin{array}{c}\text { Poor at } \\
\text { least } \\
\text { once }\end{array} \\
79.9\end{array}$} & \multirow{2}{*}{$\begin{array}{c}\begin{array}{c}\text { Average- } \\
\text { income } \\
\text { poor }\end{array} \\
70.8\end{array}$} & \multirow{2}{*}{$\begin{array}{c}\begin{array}{c}\text { Always } \\
\text { poor }\end{array} \\
61.8\end{array}$} & \multirow{2}{*}{$\begin{array}{c}\begin{array}{c}\text { Total } \\
\text { Population }\end{array} \\
70.8\end{array}$} & \multirow{2}{*}{$\begin{array}{l}\text { Non- } \\
\text { poor }\end{array}$} & \multirow{2}{*}{$\begin{array}{l}\text { Poor at } \\
\text { least } \\
\text { once }\end{array}$} & \multirow{2}{*}{$\begin{array}{c}\begin{array}{c}\text { Average- } \\
\text { income } \\
\text { poor }\end{array} \\
48.1\end{array}$} & \multirow{2}{*}{$\begin{array}{c}\begin{array}{c}\text { Always } \\
\text { poor }\end{array} \\
27.9\end{array}$} \\
\hline Head Gender & Man & & & & & & & & & & \\
\hline & Woman & 12.3 & 8.4 & 20.1 & 29.2 & 38.2 & 29.2 & & & 51.9 & 72.1 \\
\hline \multirow[t]{3}{*}{ Head Age } & $\begin{array}{l}\text { Less than } 30 \\
\text { years old }\end{array}$ & 16.9 & 14.7 & 23.0 & 24.1 & 25.3 & 17.1 & 14.8 & 25.0 & 31.3 & 44.9 \\
\hline & $\begin{array}{l}31 \text { to } 50 \\
\text { years old }\end{array}$ & 68.3 & 70.5 & 61.6 & 62.7 & 59.1 & 58.4 & 61.2 & 46.8 & 49.2 & 25.6 \\
\hline & $\begin{array}{l}51 \text { to } 65 \\
\text { years old }\end{array}$ & 14.9 & 14.8 & 15.4 & 13.2 & 15.7 & 24.5 & 24.0 & 28.2 & 19.5 & 29.5 \\
\hline \multirow{4}{*}{$\begin{array}{l}\text { Work } \\
\text { attachments }^{\text {b }}\end{array}$} & No worker & 21.1 & 11.8 & 40.2 & 63.5 & 78.1 & 15.0 & 9.1 & 40.6 & 62.4 & 45.3 \\
\hline & One worker & 51.7 & 56.8 & 41.7 & 28.1 & 19.1 & 63.7 & 66.9 & 50.5 & 34.2 & 50.2 \\
\hline & $\begin{array}{l}\text { Two } \\
\text { workers }\end{array}$ & 25.0 & 28.9 & 16.4 & 8.1 & 2.8 & 19.0 & 21.3 & 8.5 & 3.4 & 4.5 \\
\hline & $\begin{array}{l}\text { More than } \\
\text { two workers }\end{array}$ & 2.2 & 2.5 & 1.7 & 0.3 & 0.0 & 2.3 & 2.7 & 0.4 & 0.0 & 0.0 \\
\hline \multirow[t]{5}{*}{ Family type } & $\begin{array}{l}\text { Single adult, } \\
\text { no children }\end{array}$ & 6.3 & 5.1 & 8.3 & 8.9 & 18.7 & 11.0 & 10.0 & 14.3 & 17.4 & 26.3 \\
\hline & $\begin{array}{l}\text { Two adults, } \\
\text { no children }\end{array}$ & 11.9 & 13.2 & 9.3 & 6.8 & 5.1 & 12.7 & 13.3 & 10.9 & 8.0 & 10.5 \\
\hline & $\begin{array}{l}\text { Single adult, } \\
\text { children }\end{array}$ & 10.0 & 6.6 & 17.8 & 24.5 & 28.2 & 9.3 & 6.8 & 19.7 & 20.9 & 27.5 \\
\hline & $\begin{array}{l}\text { Two adults, } \\
\text { children }\end{array}$ & 65.9 & 69.4 & 57.3 & 54.7 & 45.6 & 62.0 & 66.0 & 44.0 & 50.0 & 29.8 \\
\hline & $\begin{array}{l}\text { Other } \\
\text { households }\end{array}$ & 5.9 & 5.8 & 7.4 & 5.2 & 2.3 & 5.0 & 4.0 & 11.1 & 3.8 & 5.9 \\
\hline \multirow{3}{*}{$\begin{array}{l}\text { Education } \\
\text { level of head }\end{array}$} & Low & 20.9 & 18.2 & 26.3 & 28.5 & 45.5 & 15.3 & 13.9 & 22.4 & 25.8 & 12.2 \\
\hline & Middle & 27.9 & 26.2 & 31.7 & 34.9 & 38.4 & 64.2 & 63.9 & 65.4 & 60.4 & 83.2 \\
\hline & High & 51.2 & 55.7 & 42.1 & 36.6 & 16.1 & 20.5 & 22.2 & 12.2 & 13.8 & 4.5 \\
\hline
\end{tabular}

${ }^{a}$ Characteristics defined at the beginning of the period. For each characteristic breakdown, numbers sum to $100(\%)$ by column.

${ }^{b}$ Refers to full-time employment (1750 hours or more in the base year).

${ }^{c}$ Low education is less than upper secondary education, middle is completed upper secondary education, high is tertiary education.

Source: SLID for Canada; GSOEP for Germany (all author's calculations). 
Appendix Table A (continued). Characteristics of the non-poor, short-term poor, and longer-term poor, 1991-1996 (disposable income poverty; percentage shares by category)

\begin{tabular}{|c|c|c|c|c|c|c|c|c|c|c|c|}
\hline \multirow{2}{*}{\multicolumn{2}{|c|}{ Household Characteristic ${ }^{\mathrm{a}}$}} & \multicolumn{5}{|c|}{ Great Britain } & \multicolumn{5}{|c|}{ United States } \\
\hline & & \multirow{2}{*}{$\begin{array}{c}\begin{array}{c}\text { Total } \\
\text { Population }\end{array} \\
71.5\end{array}$} & \multirow{2}{*}{$\begin{array}{l}\begin{array}{l}\text { Non- } \\
\text { poor }\end{array} \\
73.4\end{array}$} & \multirow{2}{*}{$\begin{array}{c}\begin{array}{c}\text { Poor at } \\
\text { least } \\
\text { once }\end{array} \\
68.4\end{array}$} & \multirow{2}{*}{$\begin{array}{c}\begin{array}{c}\text { Average- } \\
\text { income } \\
\text { poor }\end{array} \\
59.1\end{array}$} & $\begin{array}{l}\text { Always } \\
\text { poor }\end{array}$ & $\begin{array}{c}\text { Total } \\
\text { Population }\end{array}$ & $\begin{array}{l}\text { Non- } \\
\text { poor }\end{array}$ & \multirow{2}{*}{$\begin{array}{l}\text { Poor at } \\
\text { least } \\
\text { once } \\
73.1\end{array}$} & \multirow{2}{*}{$\begin{array}{c}\begin{array}{c}\text { Average- } \\
\text { income } \\
\text { poor }\end{array} \\
58.8\end{array}$} & \multirow{2}{*}{$\begin{array}{c}\begin{array}{c}\text { Always } \\
\text { poor }\end{array} \\
28.7\end{array}$} \\
\hline Head Gender & Man & & & & & 47.5 & 82.2 & 89.4 & & & \\
\hline & Woman & 28.5 & 26.6 & 31.7 & 40.9 & 52.6 & 17.8 & 10.6 & 26.9 & 41.2 & 71.3 \\
\hline \multirow[t]{3}{*}{ Head Age } & $\begin{array}{l}\text { Less than } 30 \\
\text { years old }\end{array}$ & 15.3 & 13.9 & 17.6 & 28.3 & 7.5 & 19.3 & 15.5 & 28.1 & 28.8 & 30.6 \\
\hline & $\begin{array}{l}31 \text { to } 50 \\
\text { years old }\end{array}$ & 67.1 & 66.4 & 70.0 & 61.5 & 91.0 & 67.0 & 70.0 & 59.0 & 59.7 & 63.4 \\
\hline & $\begin{array}{l}51 \text { to } 65 \\
\text { years old }\end{array}$ & 17.6 & 19.7 & 12.4 & 10.1 & 1.5 & 13.7 & 14.5 & 12.8 & 11.5 & 6.0 \\
\hline \multirow{4}{*}{$\begin{array}{l}\text { Work } \\
\text { Attachment }^{\mathrm{b}}\end{array}$} & No worker & 12.6 & 6.8 & 26.0 & 52.4 & 60.4 & 16.9 & 8.8 & 24.1 & 50.2 & 84.1 \\
\hline & One worker & 52.9 & 53.2 & 44.3 & 44.3 & 39.6 & 56.2 & 58.9 & 57.7 & 42.9 & 15.7 \\
\hline & $\begin{array}{l}\text { Two } \\
\text { workers }\end{array}$ & 28.4 & 32.4 & 18.3 & 3.4 & 0.0 & 25.6 & 30.6 & 17.4 & 7.0 & 0.2 \\
\hline & $\begin{array}{l}\text { More than } \\
\text { two workers }\end{array}$ & 6.2 & 7.6 & 2.0 & 0.0 & 0.0 & 1.3 & 1.6 & 0.8 & 0.0 & 0.0 \\
\hline \multirow[t]{5}{*}{ Family type } & $\begin{array}{l}\text { Single adult, } \\
\text { no children }\end{array}$ & 4.3 & 4.7 & 3.2 & 3.5 & 5.1 & 10.8 & 10.2 & 13.9 & 10.1 & 8.0 \\
\hline & $\begin{array}{l}\text { Two adults, } \\
\text { no children }\end{array}$ & 16.1 & 19.2 & 8.0 & 5.8 & 7.1 & 13.8 & 16.6 & 9.5 & 1.7 & 2.2 \\
\hline & $\begin{array}{l}\text { Single adult, } \\
\text { children }\end{array}$ & 7.5 & 5.1 & 12.3 & 22.6 & 26.5 & 13.3 & 6.3 & 21.4 & 35.9 & 71.5 \\
\hline & $\begin{array}{l}\text { Two adults, } \\
\text { children }\end{array}$ & 69.5 & 68.8 & 73.2 & 65.3 & 61.3 & 60.6 & 65.4 & 53.6 & 51.9 & 18.2 \\
\hline & $\begin{array}{l}\text { Other } \\
\text { households }\end{array}$ & 2.5 & 2.3 & 3.3 & 2.8 & 0.0 & 1.5 & 1.6 & 1.7 & 0.5 & 0.1 \\
\hline Education & Low & \multirow{3}{*}{\multicolumn{5}{|c|}{ not available }} & 11.0 & 5.8 & 16.3 & 32.4 & 49.5 \\
\hline level of head & Middle & & & & & & 36.9 & 33.4 & 46.3 & 48.7 & 37.7 \\
\hline & High & & & & & & 52.1 & 60.8 & 37.4 & 19.0 & 12.9 \\
\hline
\end{tabular}

${ }^{a}$ Characteristics defined at the beginning of the period. For each characteristic breakdown, numbers sum to $100(\%)$ by column.

${ }^{b}$ Refers to full-time employment (1750 hours or more in the base year).

${ }^{c}$ Low education is less than upper secondary education, middle is completed upper secondary education, high is tertiary education. Data not available for Great Britain.

Source: BHPS for Great Britain; PSID for the United States (all author's calculations). 